TOMASZ SZWACIŃSKI

Warszawa

\title{
ROSYJSKO-BRYTYJSKIE STOSUNKI DYPLOMATYCZNE NA SASKO-POLSKIM GRUNCIE W PRZEDEDNIU PRUSKIEJ AGRESJI. HEINRICH IWANOWICZ GROSS A DAVID MURRAY WICEHRABIA STORMONT (CZERWIEC-SIERPIEŃ 1756)*
}

Mimo objętościowego ogromu dotychczasowego dorobku historiografii dotyczącego „przewrotu przymierzy” i genezy wojny siedmioletniej w 1756 r. ${ }^{1}$ nie możemy uznać tematu za wyczerpany. Niemal zupełnie nieznany fragment tego procesu stanowią stosunki dyplomatów: brytyjskiego Davida Murray wicehrabiego Stormont i rosyjskiego Heinricha Iwanowicza Grossa w Dreźnie, w okresie między przybyciem Szkota nad Łabę a zajęciem Saksonii przez Prusaków. Zarówno na podstawie analizy szeregu źródeł opublikowanych, przywołanych we wprowadzeniu do niniejszych rozważań, jak i poprzez szczegółową analizę tytułowego zagadnienia, opartą na źródłach archiwalnych, możemy suponować, że w grze dyplomatycznej związanej z „przewrotem przymierzy”

* Artykuł ten stanowi gruntownie przebudowany fragment rozprawy doktorskiej napisanej pod kierunkiem Zofii Zielińskiej: T. Szwaciński, „Polityka rosyjska wobec Rzeczypospolitej w dobie «przewrotu przymierzy» (1754-1756)", praca doktorska Instytutu Historycznego Uniwersytetu Warszawskiego, Warszawa 2011, s. 353-375. Praca naukowa finansowana ze środków na naukę w latach 2010-2011 jako projekt badawczy (grant promotorski nr N N108 095738), a także środków przeznaczonych na badania statutowe przez Instytut Historyczny UW.

${ }^{1}$ Przegląd dyskusji, która przetoczyła się przez naukę, na temat genezy wojny siedmioletniej do początku XX w., Е. Щепкин, Русско-австрийский союз во время Семилетней войны, 1746-1758 г2., С.-Петербург 1902, s. 260-438; cenny szkic literatury dotyczący udziału Rosji w wojnie siedmioletniej przyniósł artykuł Michaela G. Müllera, Russland und der Siebenjährige Krieg. Beitrag zu einer Kontroverse, „Jahrbücher für Geschichte Osteuropas", NF, 28, 1980, s. 198-219. 
strona rosyjska zdobyła nad Brytyjczykami taktyczną przewagę. Należy także podkreślić, iż dotychczasowa literatura przedmiotu nie wykazała tego w sposób wystarczająco dobitny. Jest to efektem faktu, iż żaden $z$ badaczy nie przeprowadził konsekwentnego zestawienia i równoczesnej analizy przekazów obydwu stron. Tekst niniejszy stanowi zatem nieśmiałą propozycję metody dalszych badań stosunków Londynu i Petersburga w połowie XVIII w.

Do tej pory o kontaktach Stormonta z Grossem w tytułowym okresie wzmiankowali Władysław Konopczyński ${ }^{2}$, Herbert Kaplan ${ }^{3}$ i Paweł Hanczewski ${ }^{4}$,jednak w sposób incydentalny, nie traktując ich jako osobnego i istotnego zagadnienia, ponadto wyłącznie od strony przekazów brytyjskich.

Materiałem źródłowym, na którym został oparty niniejszy tekst, jest korespondencja dyplomatyczna Londynu z placówką w Dreźnie przechowywana w Archiwum Narodowym w Londynie ${ }^{5}$, a także korespondencja dyplomatyczna Petersburga z placówką przy dworze Augusta III przechowywana w Archiwum Polityki Zagranicznej Imperium Rosyjskiego w Moskwie. Kwerendę uzupełniającą stanowi korespondencja Londynu z placówką w Petersburgu.

W okresie europejskich zmagań w wojnie o sukcesję austriacką (1740-1748) okrzepł (zarysowujący się od 1731 r.) austriacko-brytyjsko-rosyjski blok mocarstw, w orbicie którego znajdował się dwór sasko-polski traktowany jako sprzymierzeniec drugiej kategorii. Głównych swych wrogów alianci dostrzegali we Francji, Prusach i Turcji. Na przełomie lat czterdziestych i pięćdziesiątych Rosja zerwała stosunki dyplomatyczne z Wersalem i Berlinem.

W latach 1749-1752 Rosja i Austria prowadziły sondaż partnera brytyjskiego co do możliwości zawarcia między Petersburgiem a Londynem nowej konwencji subsydialnej. Stanowisko Anglików było jednak konsekwentnie negatywne ${ }^{6}$. Sytuacja zmieniła się na jesieni $1752 \mathrm{r}$.

${ }^{2}$ W. Konopczyński, Polska $w$ dobie wojny siedmioletniej, t. 1, Kraków 1909.

${ }^{3}$ H. Kaplan, Russia and the Outbreak of the Seven Years' War, Berkeley-Los Angeles 1968.

${ }^{4}$ P. Hanczewski, Dyplomacja brytyjska w Europie Środkowo Wschodniej w latach 17481756. Misje w Berlinie, Dreźnie, Petersburgu i Wiedniu, Torun 2001.

${ }^{5}$ Wykaz skrótów: AKV - Архив князя Воронцзова, wyd. П.И. Бартенев, t. 1-40, Москва 1870-1895; AVPRI - Архив внешней политики Российской империи w Moskwie; KSZ - Kolegium Spraw Zagranicznych (Rosji); SP - State Papers w TNA; TNA - The National Archives w Londynie. Ponadto: b.p. - brak paginacji; d. - dieło; f. - fond; pr. - prezenta.

${ }^{6}$ С. М. Соловьев, История России с древнейших времен. Книга ХІІ (1749-1761). Тома 23-24, Москва 1964, s. 147-148 (pierwodruk: 1873-1874); P. Hanczewski, op. cit., s. $151-167$. 
w efekcie prowokacyjnych działań Fryderyka II. Na polecenie brytyjskiego sekretarza stanu, kierownika departamentu północnego Thomasa Pelham-Hollesa ks. Newcastle wiosną 1753 r. przedstawiciel Jerzego II w Rosji, Melchior Guy Dickens, przedstawił stronie rosyjskiej propozycję finansowania wojsk wschodniego imperium, ale dopiero w przypadku wojny. W rozpoczętych negocjacjach wzięli udział także przedstawiciel Austrii Johann Prettlack oraz dyplomata Augusta III w Rosji Johann von Funcke ${ }^{7}$. Wspomniane okoliczności skłoniły kanclerza Aleksieja Pietrowicza Biestużewa-Riumina (Aleksej Petrovič Bestužev-Rûmin) do określenia nowych celów działania, które przedstawił Elżbiecie 7/18 maja 1753 r. Podstawowe zagrożenie dla interesów rosyjskich stanowiły, wedle kanclerza, agresywne zamiary Fryderyka II. Władca ten, wywodził między innymi A.P. Biestużew-Riumin, zamierzał współpracować z Francją w celu osadzenia na tronie polskim Ludwika Franciszka Burbona księcia de Conti. Tym samym zagrażał interesowi rosyjskiemu na najważniejszym obszarze. Należało się temu przeciwstawić poprzez zawarcie nowej konwencji subsydialnej z Wielką Brytanią, co umożliwiłoby zwiększenie rosyjskiego potencjału militarnego ${ }^{8}$. Imperatorowa przychylnie odniosła się do poglądów kanclerza. 14/25 i 15/26 maja 1753 r. odbyła się w Moskwie konferencja z udziałem samej władczyni oraz najważniejszych urzędników cywilnych i wojskowych. Możemy suponować, że w opinii Rosjan konfrontacja z Fryderykiem II stała się nieuchronna, wręcz konieczna9. Jednak negocjacje utknęły w dwuletnim impasie ${ }^{10}$. Warto jeszcze dodać, że o podjętych w maju 1753 r. w Moskwie postanowieniach (obok rosyjskich sojuszników) już kilka miesięcy później dowiedział się „główny zainteresowany”, czyli Fryderyk II, a to za sprawą wywiadowczej działalności prowadzonej przez pruskiego dyplomatę w Dreźnie, Hansa Dietricha Maltzahna ${ }^{11}$.

Mimo bezowocnych negocjacji dwór londyński, obawiając się Francji i Prus, nie zarzucił myśli o nowej konwencji subsydialnej z Rosją. Po swoim

${ }^{7}$ Е. Щепкин, op. cit., s. 162-168; P. Hanczewski, op. cit., s. 173-175; R. Hanke, Brühl und das Renversement des alliances. Die antipreußische Außenpolitik des Dresdener Hofes 1744-1756, Berlin 2006, s. 258; М. Ю. Анисимов, Российская дипломатия в Европе в середине XVIII века. От Ахенского мира до Семилетней войны, Москва 2012, s. 149.

${ }^{8}$ С. М. Соловьев, op. cit., s. 192-196; М.Ю. Анисимов, op. cit., s. 150, 171.

${ }_{9}^{9}$ E. Hermann, Andeutungen über die russische Politik des Reichsgrafen Heinrich von Brühl. Vom Ende des ersten schlesischen bis zum Anfang des siebenjährigen Krieges, mit besonderer Berücksichtigung der diplomatischen Action des Geheimen Rath von Funcke am Petersburger Hofe in den Jahren 1753 und 1755, „Archiv für die Sächsiche Geschichte”, NF, t. 2, 1875, s. 41-44; Е. Щепкин, op. cit., s. 168-175; H. Kaplan, op. cit., s. 4; P. Hanczewski, op. cit., s. 175-176.

${ }^{10}$ E. Hermann, op. cit., s. 47-49; Е. Щепкин, op. cit., s. 175-179; P. Hanczewski, op. cit., s. 176-180; М.Ю. Анисимов, ор. cit., s. 150-152.

${ }^{11}$ E. Hermann, op. cit., s. 43; Е. Щепкин, op. cit., s. 175. 
powrocie z Anglii na placówkę przy dworze Augusta III we wrześniu 1754 r. sir Charles Hanbury Williams rozpoczął sondowanie Petersburga w tej sprawie za pośrednictwem swojego rosyjskiego odpowiednika, H. Grossa. Niebawem w Londynie postanowiono niezwłocznie wysłać Williamsa do Rosji, gdzie dotarł 16 czerwca $1755 \mathrm{r} .{ }^{12} \mathrm{~W}$ efekcie zaostrzającego się konfliktu Brytyjczyków z Francuzami w Ameryce Północnej Londyn zgodził się na ustępstwa, a 19/30 września 1755 r. doszło do podpisania rosyjsko-brytyjskiej konwencji subsydialnej, która przewidywała utrzymywanie przez Rosję za angielskie pieniądze wojska w Inflantach ${ }^{13}$.

Po podpisaniu konwencji odbyła się 26 IX/7 X w Petersburgu nowa konferencja z udziałem najważniejszych czynników. Zgromadzeni potwierdzili podstawowe plany rosyjskiej polityki zagranicznej sformułowane dwa i pół roku wcześniej w Moskwie. Siła ofensywna Fryderyka II miała zostać złamana przy pierwszym dogodnym momencie ${ }^{14}$. Także tym razem informacje o rosyjskich ustaleniach (via Drezno) dotarły do Berlina ${ }^{15}$.

$\mathrm{Z}$ drugiej strony Londyn oczekiwał, że rosyjski straszak sprawi, iż Fryderyk II zachowa pokój z sąsiadami i nie włączy się po stronie Ludwika XV do ewentualnej wojny francusko-brytyjskiej bądź wręcz przystanie na sojusz z Jerzym II i izolację Francji. Tym celom służyły negocjacje brytyjsko-pruskie, które rozpoczęły się w sierpniu 1755 r. ${ }^{16}$

Można zatem przyjąć, że od samego początku Rosja i Wielka Brytania wiązały ze swoim porozumieniem znacząco inne plany.

Jeszcze przed zawarciem konwencji brytyjsko-rosyjskiej z Wiednia skierowano do posła austriackiego w Petersburgu Nicolasa Esterhazego reskrypty, w których wyrażano niezadowolenie z postawy Londynu. Austriacki kanclerz Wenzel Anton Kaunitz przekazywał dyplomacie podej-

12 D. B. Horn, Sir Charles Hanbury Williams and European Diplomacy (1747-1758), London-Bombay-Sydney 1930, s. 163-164, 178-183; P. Hanczewski, op. cit., s. 179-181. Supozycję Józefa Gierowskiego („On [Williams - T. S.] to zapewne rozbudził ich [Czartoryskich - T.S.] nadzieje, że przy pomocy angielskiej da się skłonić dwór berliński i petersburski do wyrażenia wspólnej zgody na przygotowywane przez nich reformy. Nie bez inicjatywy młodego Poniatowskiego Williams został przeniesiony do Petersburga, gdzie miał współdziałać w realizacji tych planów”) należy uznać za nieporozumienie, J. A. Gierowski, Dyplomacja polska doby saskiej (1699-1763), w: Historia dyplomacji polskiej (połowa X-XX w.), red. G. Labuda, t. 2: 1572-1795, red. Z. Wójcik, Warszawa 1982, s. 434-435.

${ }^{13} \mathrm{R}$. Waddington, Louis XV et la renversement des alliances. Préliminaires de la Guerre de Sept Ans. 1754-1756, Paris 1896, s. 152-154; D. B. Horn, op. cit., s. 183-192; H. Kaplan, op. cit., s. 22-24; P. Hanczewski, op. cit., s. 181-183.

${ }^{14}$ E. Hermann, op. cit., s. 55-56; Е. Щепкин, op. cit., s. 244.

${ }^{15}$ H. Kaplan, op. cit., s. 32, 34-35.

${ }^{16}$ R. Waddington, op. cit., s. 197-217; H. Kaplan, op. cit., s. 10-12, 17-20, 29-35. 
rzenia o tajnych negocjacjach brytyjsko-pruskich. Gdyby Williams zaczął zwlekać z podpisaniem porozumienia z Rosją, oznaczałoby to, wedle Austriaków, że wspomniane podejrzenia były prawdziwe i należało podzielić się nimi z Rosjanami ${ }^{17}$. Esterhazy otrzymał reskrypt już po podpisaniu konwencji i donosił do Wiednia, że nie zauważył nic podejrzanego w działaniach dyplomaty brytyjskiego ${ }^{18}$. Siergiej Sołowiow (Sergej Mihajlovič Solov'ev) przypuszczał, że Esterhazy jednak zdradził wrogom A.P. Bestużewa-Riumina na dworze rosyjskim posiadane przez siebie informacje ${ }^{19}$. Natomiast Kaplan sugerował możliwość rosyjskiej perlustracji depesz z Londynu ${ }^{20}$, co wydaje się mniej prawdopodobne ${ }^{21}$. Jednak bez względu na źródło nie należy wykluczać przecieku ${ }^{22}$. Niewykluczone także, że do Petersburga zawczasu dotarły informacje o awansach czynionych przez Kaunitza wobec dworu arcychrześcijańskiego ${ }^{23}$. Ponadto można przypuszczać, że Michaiłowi Iłłarionowiczowi Woroncowowi (Mihail Illarionovič Voroncov) dała do myślenia pierwsza sondażowa misja agenta sekretu Ludwika XV Alexandra Mackenziego Douglasa, który w październiku 1755 r. przebywał trzy tygodnie nad Newą i sugerował

${ }^{17}$ Maria Teresa do N. Esterhazego, Wiedeń, 9 IX 1755 (fragmenty), Preussische und Österreichische Acten zur Vorgeschichte des Siebenjährigen Krieges, wyd. G. B. Volz, G. Küntzel, Leipzig 1899, Publicationen aus den K. Preussischen Staatsarchiven, t. 74 (dalej: Publicationen 74), s. 165-166; W. Kaunitz do N. Esterhazego, Wiedeń, 9 IX 1755 (fragmenty), Publicationen 74, s. 166-167. Z przytoczonych przez E. Szczepkina dosłownych cytatów (miejscami szerszych niż w Publicationen 74) wynika, że znał on cały tekst przechowywany w archiwum w Wiedniu, Е. Щепкин, op. cit., s. 245-248.

${ }^{18}$ N. Esterhazy do W. Kaunitza, Petersburg, 7 X 1755 (fragmenty), Publicationen 74, s. 183-184; por. Е. Щепкин, op. cit., s. 248.

${ }^{19}$ С. М. Соловьев, ор. cit., s. 313.

${ }^{20}$ H. Kaplan, op. cit., s. 36-38.

${ }^{21}$ Supozycję H. Kaplana osłabia fakt, że hr. Holdernesse donosił Williamsowi o negocjacjach z Prusakami 26 grudnia 1755 r. Cała depesza została zaszyfrowana i wysłana kurierem, R. D'Arcy earl of Holdernesse (dalej: Holdernesse) do Ch. Hanbury'ego Williamsa (dalej: Williams), Londyn-Whitehall, 26 XII 1755 („most secret”), TNA, SP 91/61, k. 189-199v.

${ }^{22}$ P. Hanczewski (op. cit., s. 184, 192) stwierdził: „Całkowicie w sferze domysłów pozostaje sugestia jednego z historyków, iż Rosjanie mogli już wtedy wiedzieć o kontaktach brytyjsko-pruskich i z tego względu zwlekali z wymianą ratyfikacji. Nie potwierdzają jej dokumenty, a koronny argument przeciw niej stanowi fakt, że jednak doszło do wymiany dokumentów". Hanczewski przywołuje w przypisie H. Kaplana (op. cit., s. 31-32, 38) i S. Sołowiowa (op. cit., s. 249-250). „Koronny argument” Hanczewskiego jest w tym przypadku bezwartościowy, zważywszy, że rosyjska ratyfikacja miała warunkowy charakter (o czym niżej).

${ }^{23}$ Oficjalne oświadczenie austriackie o negocjacjach Wiednia z Wersalem zostało uczynione Rosjanom w początkach kwietnia 1756 r. (Е. Щепкин, op. cit., s. 519-521), tymczasem już 3/14 marca w zapytaniu do KSZ Elżbieta stwierdziła „что по публичным ведомостиям разглашается, якобы венский двор с Францею некоторыя потаемныя соглашения чинит" (SIRIO, t. 136, С. Петербург 1912, s. 23). 
wicekanclerzowi możliwość odnowienia stosunków dyplomatycznych miedzy Francją a Rosją ${ }^{24}$.

Bez względu na to, jaki był jesienią 1755 r. rzeczywisty stan wiedzy rosyjskich dygnitarzy na temat zachodzących jeszcze podskórnie przemian systemu europejskiego, wrogom A.P. Biestużewa-Riumina udało się skłonić imperatorową do wątpliwości, Elżbieta zaczęła bowiem zwlekać z podpisaniem ratyfikacji konwencji ${ }^{25}$. Chcąc wpłynąć na władczynię, kanclerz przekonywał ją w memoriale przedstawionym 19/30 stycznia 1756 r., że tylko w porozumieniu z Wielką Brytanią Rosja będzie miała możliwość okiełznania Fryderyka II i uniemożliwienia mu prowadzenia intryg w Szwecji, Polsce i Turcji ${ }^{26}$. Gdy ostatecznie 1/12 lutego 1756 r. doszło do wymiany ratyfikacji, strona rosyjska przyłączyła do nich deklarację, że walczyć będzie tylko z królem Prus ${ }^{27}$.

Takie stanowisko było dla Anglików nie do zaakceptowania, gdyż wykorzystali oni konwencję subsydialną, aby skłonić Fryderyka II do porozumienia. 16 stycznia 1756 r. Wielka Brytania i Prusy zawarły tzw. konwencję westminsterską, obie strony zagwarantowały sprzeciw wobec wkroczenia obcych wojsk w granice cesarstwa ${ }^{28}$.

4/15 lutego $1756 \mathrm{r}$. Williams poinformował stronę rosyjską o konwencji westminsterskiej ${ }^{29}$. Reakcja dworu rosyjskiego na oficjalną informację o porozumieniu brytyjsko-pruskim była od samego początku negatywna. Już 8/19 lutego wysłano do Aleksandra Michajłowicza Golicyna (Aleksandr Mihajlovič Golicyn) reskrypt, w którym jednoznacznie

${ }^{24}$ L. Jay Oliva, Misalliance. A Study of French Policy in Russia During the Seven Years' War, New York 1964, s. 13-22; H. Kaplan, op. cit., s. 12-14, 24-28; П. П. Черкасов, Двуглавый Орёл и Королевские Лилии. Становление русско- франиузских отношений в XVIII веке. 1700-1775, Москва 1995, s. 88-92; М. Ю. Анисимов, ор. cit., s. 172-173.

${ }^{25}$ P. Hanczewski, op. cit., s. 183-184; М.Ю. Анисимов, 152-153.

${ }^{26}$ С. М. Соловьев, op. cit., s. 313-317; Н. Kaplan, op. cit., s. 39-40; М. Ю. Анисимов, op. cit., s. 154.

${ }^{27}$ Rosyjska deklaracja tajna wręczona Williamsowi, [Petersburg] 1/12 II 1755, Coбрание трактатов и конвенций, заключенных Россией с иностранными державами, wyd. Ф. Мартенс, t. 9 (10): Трактаты с Англей. 1710-1801, С. Петербург 1892, s. 201-203. Williams przyjął tekst deklaracji i wysłał go do Londynu, skąd przyszły wytyczne, aby zwrócić go stronie rosyjskiej. Gdy dyplomata zastosował się do niego (8 V 1756), Rosjanie przekazali Anglikom tekst za pośrednictwem A.M. Golicyna. Także tym razem w Londynie go nie przyjęto. Fryderyk II został poinformowany o rosyjskich warunkach dopiero 6 lipca 1756 r. Е. Щепкин, op. cit., s. 318, 527; H. Kaplan, op. cit., s. 86-87; P.F. Doran, Andrew Mitchell and Anglo-Prussian diplomatic relations during the Seven Years War, New York-London 1986, s. 61-62, 92; P. Hanczewski, op. cit., s. 192-195.

${ }^{28}$ R. Waddington, op. cit., s. 217-221; W. Konopczyński, op. cit., s. 76, 78, 345;

H. Kaplan, op. cit., s. 20-22, 33-35; P.F. Doran, op. cit., s. 17-27.

${ }^{29}$ С. М. Соловьев, оp. cit., s. 319-320. 
wyrażono niezadowolenie z powodu zbliżenia Berlina i Londynu ${ }^{30}$. Ponadto, 19 II/1 III Esterhazy przedstawił obydwu kanclerzom stanowisko Marii Teresy, która wyraziła swe rozgoryczenie polityką Albionu, radziła jednak przyjęcie postawy wyczekującej ${ }^{31}$.

3/14 marca Elżbieta nakazała Kolegium Spraw Zagranicznych przedstawić opinię na temat środków, które należało podjąć w obliczu zbliżenia prusko-brytyjskiego i informacji o planowanym porozumieniu francusko-austriackim ${ }^{32}$. W imieniu KSZ M. I. Woroncow, Iwan Pugowisznikow (Ivan Osipovič Pugovišnikov) i Adam Ołsufjew (Adam Vasil'evič Olsuf'ev) opowiedzieli się za natychmiastowym wypowiedzeniem konwencji z Jerzym II. Nie uważali także, aby zbliżenie Wersalu i Wiednia było groźne dla Rosji ${ }^{33}$. Natomiast kanclerz w osobnej opinii oświadczył, że choć zbliżenie brytyjsko-pruskie niszczy podstawowy cel konwencji subsydialnej, jednak radził nie wypowiadać porozumienia ze względów taktycznych ${ }^{34}$. Także korespondencja A.P. Biestużewa-Riumina z A. M. Golicynem z tego okresu wskazuje, że pieczętarz mógł liczyć na rozpad konwencji westminsterskiej ${ }^{35}$. Wszelako, wobec konsekwentnej postawy Anglików, musiał zostać zrealizowany scenariusz, w którym rezygnacja z natychmiastowego wypowiedzenia konwencji subsydialnej była w istocie rosyjskim podstępem.

Podczas pierwszych posiedzeń powołanej wówczas w formie stałego organu Konferencji Przy Najwyższym Dworze (KPND) pod koniec marca 1756 r. politycy rosyjscy opracowali plan działania w nowych warunkach. Za radą A.P. Biestużewa-Riumina nie podjęto decyzji o natychmiastowym zerwaniu konwencji z Wielką Brytanią. $Z$ drugiej jednak strony konferencja postanowiła, że aby uśmierzyć austriackie obawy przed dywersją króla arcychrześcijańskiego, należało rozpocząć starania o neutralizację Francji w konflikcie z Fryderykiem II. Rosja parła do wojny,

${ }^{30}$ Elżbieta I do A. M. Golicyna, Petersburg, 8/19 II 1756, SIRIO, t. 136, s. 6-10.

${ }^{31}$ Maria Teresa do N. Esterhazego, Wiedeń, 11 II 1756 (ostensibel, fragmenty), Publicationen 74, s. 223-224; pełne tłumaczenie tegoż na rosyjski z informacją o dacie przedstawienia tekstu przez N. Esterhazego stronie rosyjskiej, SIRIO, t. 136, s. 11-23; por. Е. Щепкин, op. cit., s. 497-506. Cztery miesiące później A.P. Biestużew-Riumin przekonywał Williamsa, że także dzięki działalności Esterhazego udało się zapobiec natychmiastowemu wypowiedzeniu przez Rosję konwencji subsydialnej. Był to typowy przykład dezinformacji poprzez półprawdy. Tym razem Anglik nie uwierzył. Williams do Holdernesse'a, Petersburg, 6 i 9 VII 1756 (pr. 4 VIII), TNA, SP 91/63, b.p.

32 Zapytanie Elżbiety I do KSZ, [Petersburg] 3/14 III 1756, SIRIO, t. 136, s. 23.

${ }^{33}$ Opinia KSZ, [Petersburg, marzec 1756], SIRIO, t. 136, s. 23-27; por. H. Kaplan, op. cit., s. 51-52.

${ }^{34}$ Oddzielna opinia A.P. Biestużewa-Riumina, [Petersburg, marzec 1756], SIRIO, t. 136, s. 27-29; por. H. Kaplan, op. cit., s. 52-53.

${ }^{35}$ М. Ю. Анисимов, s. 157-158. 
której celem miał być rozbiór posiadłości Hohenzollernów. Temu celowi służył wypracowany w toku obrad KPND „systematyczny plan ograniczenia sił króla pruskiego". Przewidywano wykorzystanie odzyskania przez Austrię Śląska, w celu dokonania jednostronnej aneksji wschodnich obszarów Rzeczypospolitej ${ }^{36}$.

Kryzys w relacjach austriacko-brytyjskich spowodował, że w Wiedniu odżyły plany porozumienia z Francją. Od pół roku toczyły się w Wersalu niemrawe negocjacje między obydwoma dworami, lecz konwencja westminsterska nadała im nowy wigor ${ }^{37}$. W marcu $1756 \mathrm{r}$. Maria Teresa postanowiła przedstawić Elżbiecie swoje plany zagwarantowania sobie z Ludwikiem XV wzajemnej neutralności i zapytać, czy rosyjska imperatorowa wyrażałaby życzenie przyłączenia się do tego ewentualnego porozumienia ${ }^{38}$. W oddzielnym i tajnym reskrypcie poinformowano także Esterhazego, że Wiedeń rozważał zawarcie z Wersalem traktatu obronnego służącego pośredniemu współdziałaniu Francji w dziele odzyskania przez Austrię Śląska. Dyplomacie polecono wysondować stanowisko Rosjan, przy zachowaniu możliwie głębokiego sekretu (zwłaszcza przed Williamsem) ${ }^{39}$. Wobec podjętych przez KPND decyzji, gdy Esterhazy w początkach kwietnia rozpoczął wprowadzanie obu kanclerzy i Elżbiety w zamierzenia swego dworu wobec Francji, reakcja Rosjan była wręcz entuzjastyczna. Skłoniło to dyplomatę do przedstawienia w zasadzie wszystkich posiadanych przez siebie informacji na temat zamierzeń Marii Teresy. Elżbieta zadeklarowała, że w przypadku powodzenia negocjacji wersalskich Rosja przystąpi do tego porozumienia, zobowiązując się jednocześnie do zachowania na razie najgłębszego sekretu. Imperatorowa wyraziła ponadto wolę zawarcia z Marią Teresą nowego, ofensywnego traktatu ${ }^{40}$.

${ }^{36}$ Protokoły i materiały posiedzeń KPND, Petersburg, 14/25, 15/26, 18/29 III 1756, SIRIO, t. 136, s. 1-36; por. С. М. Соловьев, op. cit., s. 322-324; H. Kaplan, op. cit., s. 47-56; Б. В. Носов, Установление Российского Господства в Речи Посполитой. 1756-1768, Москва 2004, s. 14-15. Warto podkreślić, że plany nowych zdobyczy terytorialnych kosztem zachodniej sąsiadki snuł Piotr I (J. Burdowicz-Nowicki, Piotr I, August II i Rzeczpospolita, Kraków 2010, s. 342-347), w czasach Elżbiety Piotrówny koncepcje takie pojawiały się przynajmniej od 1744 r., F. von Raumer, Contributions to Modern History from the British Museum and the State Paper Office. Frederick II and His Times, London 1837, s. 152; Е. Щепкин, op. cit., s. 26-28; W. Konopczyński, Anglia wobec niedoszłej pacyfikacji prusko-rosyjskiej 1760-1 r., KH 25, 1911, s. 36; idem, Pierwszy rozbiór Polski, Kraków 2010, s. 52; Z. Zielińska, Pogłoski o rozbiorze Polski oraz ich reperkusje w Rzeczypospolitej w okresie bezkrólewia 1763-1764 r., PH 106, 2005, z. 4, s. 545.

${ }^{37}$ R. Waddington, op. cit., s. 284-332.

${ }^{38}$ Maria Teresa do N. Esterhazego, Wiedeń, 13 III 1756 (ostensible, obszerne cytaty i omówienie), Е. Щепкин, op. cit., s. 510-513.

${ }^{39}$ Maria Teresa do N. Esterhazego, Wiedeń, 13 III 1756, Publicationen 74, s. 258 265; por. Е. Щепкин, op. cit., s. 513-518.

${ }^{40}$ N. Esterhazy do Marii Teresy i W.A. Kaunitza, Petersburg, 5, 6, 13, 22 IV 1756 
Konwencja westminsterska sprawiła także, że bezprzedmiotowa stała się sprawa pozyskania przez Saksonię nowych subsydiów brytyjskich ${ }^{41}$. Rosja z początkiem 1756 r., choć nie bez oporów i gry na zwłokę, zadeklarowała wsparcie dla tych negocjacji ${ }^{42}$. Po porozumieniu brytyjsko-pruskim zarówno dla Austriaków, jak i dla Rosjan odmowa dalszego finansowania Drezna przez Londyn była jednym z dowodów na nielojalną wobec starych sojuszników postawę Albionu ${ }^{43}$.

Przedstawienie przez A.M. Golicyna instrukcji, które otrzymał z Petersburga, do pewnego stopnia zaniepokoiło kierownictwo brytyjskiej polityki zagranicznej ${ }^{44}$. Jednak Williams donosił swojemu dworowi 11 kwietnia 1756 r. o nadzwyczajnych sukcesach A.P. Biestużewa-Riumina w utrzymaniu traktatu subsydialnego z Wielką Brytanią, których efektem było przeciągnięcie większości KPND na stronę kanclerza. Dyplomata największe zagrożenie upatrywał w działaniach Esterhazego i przekonywał swój dwór, że podstawą rozgoryczenia Rosjan nie była sama konwencja westminsterska, ale fakt nieuprzedzenia Petersburga o zamiarze jej zawarcia ${ }^{45}$. Tymczasem miesiąc później A. M. Golicynowi został do Londynu wysłany reskrypt, w którym imperatorowa zadeklarowała, że uważa konwencję subsydialną za zerwaną. Zabroniono przy tym dyplomacie informować Anglików o stanowisku rosyjskim ${ }^{46}$. Całkowicie błędna diagnoza Williamsa odnośnie do sytuacji na dworze petersburskim i polityki Rosji nie może budzić wątpliwości; w efekcie, mimo wyraźnych obaw, Anglicy wciąż żywili nadzieję, że Elżbieta pozostanie w sojuszu z nimi ${ }^{47}$. W połowie maja świeżo przybyły nad Sprewę Andrew Mitchell zapewnił pełnego niepokoju o stanowisko rosyjskie Fryderyka II, że Londyn był pewny wierności Petersburga ${ }^{48}$.

(łącznie 6 depesz, fragmenty), Publicationen 74, s. 301-305, 313-320; por. R. Waddington, op. cit., s. 353; Е. Щепкин, op. cit., s. 519-522; М. Ю. Анисимов, op. cit., s. 135.

${ }^{41}$ P.F. Doran, op. cit., s. 34, 47-48; R. Hanke, op. cit., s. 278-291.

${ }^{42}$ T. Szwaciński, op. cit., s. 159-197.

${ }^{43}$ Maria Teresa do N. Esterhazego, [Wiedeń, 11 II 1756] (tłumaczenie ros.), SIRIO, t. 136, s. 17; Elżbieta I do A. M. Golicyna, Petersburg, 8/19 II 1756, ibidem, s. 10.

${ }^{44}$ Holdernesse do Williamsa, Londyn-Whitehall, 30 III 1756 (separate and secret), TNA, SP, 91/62, b.p.

${ }^{45}$ Williams do Holdernesse'a, Petersburg, 11 IV 1756 (pr. 5 V), TNA, SP 91/62, b.p.; por. H. Kaplan, op. cit., s. 53-54; P. Hanczewski, op. cit., s. 114, 193. Depeszę Williamsa z 11 kwietnia okazał Fryderykowi II Mitchell 24 maja jako dowód, że Anglicy panują nad sytuacją w Petersburgu, Е. Щепкин, op. cit., s. 301-302.

${ }^{46}$ Elżbieta I do A. M. Golicyna, [Petersburg] 5/16 V 1756 (fragmenty), Н. Н. Яковлев, Россия и Великобритания накануне Семилетней войны: от союза к конфронтац̧ии, w: idem, Британия и Европа, Москва 2000, s. 207.

${ }^{47}$ A. M. Golicyn do Elżbiety I, [Londyn] 17/28 V 1756 (fragmenty), С. М. Соловьев, op. cit., s. 364-366.

${ }^{48}$ A. Mitchell do Holdernesse'a, 14 V 1756 (fragmenty), F. von Raumer, op. cit., s. 254-256; por. Е. Щепкин, op. cit., s. 300-301; P. F. Doran, op. cit., s. 51-55, 90-91. 
Podczas posiedzenia KPND w dniach 4/15 i 6/17 kwietnia 1756 r. postanowiono nakazać dyplomatom rosyjskim uzasadnianie rosyjskiej koncentracji w Inflantach pragnieniem wykonania sojuszniczych zobowiązań wobec Jerzego II $^{49}$. Jednak na ściśle tajnej konferencji kanclerzy rosyjskich z Esterhazym 9/20 kwietnia 1756 r., zdradzono dyplomacie, że wyrażona w reskryptach cyrkularnych deklaracja o gotowości wypełnienia sojuszniczych zobowiązań wobec Wielkiej Brytanii służyła przykryciu prawdziwych celów koncentracji wojsk w Inflantach. Ponadto Petersburg zadeklarował gotowość zawarcia wymierzonego w Berlin, ofensywnego sojuszu z Wiedniem, a także wolę przyłączenia się Elżbiety do ewentualnego porozumienia Marii Teresy i Ludwika XV. W celu wsparcia negocjacji austriacko-francuskich miał zostać wysłany do dyplomatów Elżbiety akredytowanych przy dworach zagranicznych reskrypt cyrkularny nakazujący uprzejme traktowanie francuskich kolegów ${ }^{50}$. Wdrożono także Austriaków w podstawowe założenia „systematycznego planu" ${ }^{51}$. Wedle deklaracji złożonej Esterhazemu w przypadku powodzenia negocjacji Rosjanie planowali już w sierpniu zaatakować Fryderyka II ${ }^{52}$. Pod koniec maja Esterhazy poinformował stronę rosyjską o zawarciu (1 V 1756) w Wersalu francusko-austriackiego traktatu obronnego ${ }^{53}$.

W kwietniu 1756 r. Douglas powrócił do Petersburga, a 7/18 maja otrzymał zapewnienie Elżbiety, że pragnie ona wznowienia stosunków dyplomatycznych z Francją ${ }^{54}$. Wedle Esterhazego szczegóły działalności francuskiego emisariusza nad Newą początkowo pozostawały poza wiedzą A.P. Biestużewa-Riumina, który musiał opierać się na pośrednich źródłach informacji. Na polecenie Elżbiety kontaktami z Douglasem zajmował się Woroncow, co, wedle austriackiego dyplomaty, świadczyło

${ }^{49}$ Protokół KPND, Petersburg, 4/15 i 6/17 IV 1756, SIRIO, t. 136, s. 73-74.

${ }^{50}$ Notatka dla Elżbiety I o konferencji A.P. Biestużewa-Riumina i M.I. Woroncowa z N. Esterhazym, [Petersburg] 9/20 IV 1756, AKV, t. 3, Москва 1871, s. 384-386. Wspomniane reskrypty cyrkularne, pierwszy o Francji, drugi o Wielkiej Brytanii: Elżbieta I do H. Grossa, Petersburg, 13/24 IV i 27 IV/8 V 1756 (reskrypty cyrkularne nr 21 i 24), AVPRI, f. 79/1, d. 1756/5, k. 106-107, 116-117v; patrz też: Е. Щепкин, op. cit., s. 303-305, 523-528; H. Kaplan, op. cit., s. 59-60, 62; М. Ю. Анисимов, op. cit., s. 136. Williams dowiedział się o reskryptach w sprawie Francji dwa miesiące później i bagatelizował ten fakt, Williams do Holdernesse'a, Petersburg, 26 VI, 9 VII 1756 (pr. 20 VII, 4 VIII, druga depesza „private and secret”), TNA, SP 91/63, b.p.; por.: P. Hanczewski, op. cit., s. 187.

${ }^{51}$ Nota wręczona N. Esterhazemu, [Petersburg] 9/20 IV 1756 (zał. do rel. Esterhazego z 22 IV), Publicationen 74, s. 321-323; wersja rosyjska tegoż, AKV, t. 3, s. 387-390.

${ }^{52}$ Е. Щепкин, op.cit., s. 525-526.

53 Ibidem, s. 530.

${ }^{54}$ C. М. Соловьев, op. cit., s. 356-357; R. Waddington, op. cit., s. 353-354; H. Kaplan, op. cit., s. 45-46, 62-65. 
o podważeniu pozycji kanclerza ${ }^{55}$. Niebawem na placówkę do Paryża wyruszył Fiodor Dimitriewicz Biechtiejew (Fëdor Dmitrievič Behteev), a Rosjanie dali znać Francuzom, że nie zamierzają wykonywać postanowień konwencji subsydialnej ${ }^{56}$.

Jednocześnie armia rosyjska rozpoczęła koncentrację w Inflantach ${ }^{57}$ i dopiero na prośbę Esterhazego (dwór austriacki obawiał się zbyt wczesnego sprowokowania Fryderyka II) w połowie czerwca wstrzymano marsz wojsk ${ }^{58}$. Także tym razem Williamsa nie dopuszczono do prawdziwych informacji. Dyplomata brytyjski był przekonany, że wstrzymanie przygotowań wojennych to skutek niedoborów w zaopatrzeniu wojska, o czym zapewniał go A.P. Biestużew-Riumin ${ }^{59}$.

Należy zatem podsumować, że w momencie krytycznym dla Wielkiej Brytanii (traktat wersalski oraz oficjalna deklaracja wojny z Francja 17 V 1756) politycy londyńscy otrzymywali całkowicie fałszywe informacje o sytuacji w Petersburgu.

Relacja Williamsa z 11 kwietnia 1756 r. dotarła do Londynu 5 maja ${ }^{60}$. Niebawem na placówkę w Dreźnie wyruszył z brytyjskiej stolicy wicehrabia Stormont.

David Murray urodził się w 1727 r. W 1748 r. (po śmierci ojca) został siódmym wicehrabią (viscount) Stormont. Zakończywszy edukację w Oxfordzie, przez kilka lat odbywał grand tour ${ }^{61}$. W listopadzie 1755 r. rozważano możliwość mianowania go ministrem przy dworze Fryderyka II,jednak ostatecznie zapadła decyzja o wysłaniu Stormonta na placówkę do Drezna, od siedmiu miesięcy - kiedy to, wyjeżdżając do Petersburga, opuścił ją Ch. Hanbury Williams - obsadzoną jedynie przez sekretarza Fredericka Lawrence'a. Jego nominację wiązano z przeciwdziałaniem ewentualnemu zawarciu francusko-saskiego traktatu subsydialnego, dzięki

${ }^{55}$ Е. Щепкин, op. cit., s. 529-530. A.P. Biestużew-Riumin ze wspomnianych źródeł pośrednich (perlustracja, Esterhazy) wiedział, że negocjacje z Douglasem odbywały się za zgodą imperatorowej (ibidem, s. 530), jednak gdy indagował go w tej sprawie Williams, pieczętarz wyparł się wszelkiej wiedzy, Williams do Holdernesse'a, Petersburg, 4 V 1756 (pr. 2 VI), TNA, SP 91/62, b.p.

${ }^{56}$ H. Kaplan, op. cit., s. 75-76.

${ }_{57}$ С. М. Соловьев, оp. cit., s. 324; Е. Щепкин, op. cit., s. 522-523; H. Kaplan, op. cit., S. 57-58.

${ }^{58}$ С. М. Соловьев, op. cit., s. 326-327; H. Kaplan, op. cit., s. 84-86.

${ }^{59}$ Williams do Holdernesse'a, Petersburg, 6-9 i 9 VII 1756 (pr. 4 VIII, druga depesza „private and secret”), TNA, SP 91/63, b.p.

${ }^{60}$ Prezenta depeszy Williamsa z 11 IV 1756, TNA, SP 91/62, b.p.

${ }^{61}$ J. M. Rigg, Murray David, w: Dictionary of National Biography, t. 39, London 1894, s. 355; H.M. Scott, Murray David seventh Viscount Stormont and second earl of Mansfield (1727-1796), w: Oxford Dictionary of National Biography, vol. 39, Oxford 2004, s. 884-885. 
ofertom przedłużenia finansowania elektoratu przez dwór Jerzego $\mathrm{II}^{62}$, jednak sprawa rychło stała się nieaktualna i z tym można wiązać opóźnienia w wysłaniu Stormonta. Była to pierwsza samodzielna placówka młodego dyplomaty, na którą wyruszył w drugiej połowie maja 1756 r. $^{63}$ Bardzo prawdopodobne, że przed wyjazdem został zapoznany z treścią kwietniowych doniesień Williamsa, zatem jego wiedza na temat bieżącej polityki rosyjskiej była fałszywa, a działać miał przecież na terenie nie bez słuszności uznawanym za strefę wpływów wschodniego imperium.

9 czerwca 1756 r. Stormont dotarł do Drezna ${ }^{64}$. Rano 11 czerwca odbyło się pierwsze spotkanie brytyjskiego dyplomaty z jego rosyjskim kolegą akredytowanym przy dworze Augusta III, Grossem ${ }^{65}$.

Heinrich Gross urodził się w 1714 r. w Stuttgarcie w plebejskiej rodzinie austriackiego kapitana. Wykształcenie uzyskał na uniwersytecie w Tybindze. Młody Wirtemberczyk związał swe losy z Rosją dzięki protekcji starszego brata Christiana Friedricha (profesora w petersburskiej Akademii Nauk), który zarekomendował go Antiochowi Kantemirowi, rosyjskiemu dyplomacie w Londynie. Gross przyjęty został na służbę rosyjską w 1736 r., a dwa lata później wraz z Kantemirem przeniósł się na placówkę do Paryża, gdzie w 1741 r. uzyskał rangę sekretarza poselstwa. Po śmierci swojego protektora w 1744 r. został akredytowany przy dworze króla arcychrześcijańskiego. Wyraźnie zaznaczyła się wówczas protekcja, jakiej udzielał Grossowi A.P. Biestużew-Riumin. Kanclerz chciał go nawet ściągnąć do Petersburga i zatrudnić w KSZ. Na to jednak nie zgodziła się Elżbieta, zatem Heinrich Iwanowicz (jak niekiedy się pisał, choć nie ma świadectw jego konwersji na prawosławie) pozostał na paryskiej placówce. W latach następnych awansował na ministra i ministra pełnomocnego. W 1749 r. opuścił placówkę paryską, zgodnie z rozkazem z Petersburga, bez audiencji pożegnalnej u Ludwika XV. Oznaczało to zerwanie stosunków dyplomatycznych między Francją a Rosją. Następnie

${ }^{62}$ F. Lawrence do Holdernesse'a, Drezno, 24 XII 1755, TNA, SP 88/77, k. 207-208v; „И так ЕВ-а намерение было с Саксонею яко курфристом гановерском в некоторые обязательства вступить и что вскоре министр их в Дрезден назначен будет, о котором он князь Голицын думает, что некто из шотляндских лордов называемой виконт Стормонт, молодой человек, которой хотя еще и нигде определен не был однакож много хвален, туда послан будет", Elżbieta I do H. Grossa, Petersburg, 2/13 I 1756 (reskrypt nr 1), AVPRI, f. 79/1, d. 1756/5, k. 14v-15; P.F. Doran, op. cit., s. $31,46$.

${ }^{63}$ D. Murray viscount Stormont (dalej Stormont) do Holdernesse'a, Kolonia, 26 V 1756, TNA,SP 88/78,k.33.O zadaniach Stormonta w Kolonii patrz: P.F.Doran, op.cit., s. 53,90.

${ }^{64}$ Stormont do Holdernesse'a, Drezno, 12 VI 1756, TNA, SP 88/78, k. 38v.

${ }^{65}$ H. Gross do Elżbiety I, Drezno, 31 V/11 VI 1756 (rel. nr 54), AVPRI, f. 79/1, d. $1756 / 6 a, k .293 \mathrm{v}$. 
Gross został wyznaczony na placówkę do Berlina, z którego nakazano mu wyjechać w 1750 r. Również w tym przypadku wyjazd oznaczał zerwanie stosunków Berlina i Petersburga. Po krótkim pobycie w Rosji w 1752 r. został akredytowany przy dworze sasko-polskim w Dreźnie ${ }^{66}$. Kilkuletnia współpraca z Williamsem nad Sprewą, Łabą, Wisłą i Niemnem sprawiała, że Grossa uważano w Londynie za człowieka oddanego interesom Albionu ${ }^{67}$. W 1754 r. Anglicy uważali wręcz, że Gross mógł pozytywnie wpływać na powodzenie negocjacji subsydialnych w Petersburgu $^{68}$. Jednak był to dyplomata wystarczająco doświadczony i lojalny, aby prawidłowo wykonywać swoje obowiązki i nie stać się narzędziem cudzych intryg. Na marcowych posiedzeniach KPND podjęto decyzję (później zarzuconą), aby zastąpić go na placówce drezdeńskiej Michaiłem Piotrowiczem Biestużewem-Riuminem (Mihail Petrovič Bestužev-Rûmin), przedstawicielem koterii profrancuskiej. Sam Gross miał zostać członkiem $\mathrm{KSZ}^{69}$. W połowie maja otrzymał reskrypt cyrkularny (z 13/24 kwietnia) nakazujący uprzejme traktowanie francuskich kolegów. Odpowiadając, podkreślił, że także ze strony ambasadora francuskiego przy dworze sasko-polskim Charles'a François Broglie'a została okazana dobra wola ${ }^{70}$. Niebawem dotarł do niego także kolejny cyrkularz (z 27 IV/ $8 \mathrm{~V}$ 1756), w którym nakazano uzasadnianie rosyjskiej mobilizacji w Inflantach pragnieniem Elżbiety wykonania zobowiązań wobec Jerzego II. Otrzymany tekst wykorzystał, zapewniając Heinricha Brühla, że rozsiewane jakoby w Rzeczypospolitej przez zwolenników Czartoryskich plotki, iż wojsko rosyjskie idzie na pomoc „familii”, były fałszywe, a także dementował pogłoski, że Elżbieta wypowiedziała konwencję subsydialną ${ }^{71}$.

${ }^{66}$ Н.Н. Бантыш-Каменский, Обзор внешних сношений России (по 1800 год), Москва 1894-1902, cz. 1, s. 141, cz. 3, s. 260, cz. 4, s. 67-70, 102-107, 261; Д. Н. Бантыш-Каменский, Словарь достопамятных людей Русской земли, сz. 1, Санктпетербург 1847, s. 452-458; С. М. Соловьев, op. cit., s. 52-55; S. L. Turiłowa, Rosyjscy przedstawiciele dyplomatyczni w Rzeczypospolitej w XVII-XVIII w., oprac. E. Zielińska, KH 105, 1998, 2, s. 76; М. Ю. Анисимов, ор. cit., s. 37, 56-59, 78-19, 104.

${ }^{67}$ K. Waliszewski, Potoccy i Czartoryscy, Kraków 1887, s. 165-166; W. Konopczyński, Sejm Grodzieński, KH 21, 1907, s. 84; idem, Polska w dobie, t. 1, s. 10, 14-21, 316-322 (nie sposób jednak zgodzić się z konstrukcją myślową tego autora - „Williams i podległy jego wpływowi Gross"); P. Hanczewski, op. cit., s. 78, 81, 97, 106, 179; T. Szwaciński, op. cit., s. 22, 32, 44-151.

${ }^{68}$ Holdernesse do Williamsa, Londyn-Whitehall, 20 IX 1754 („secret”), TNA, SP 88/76, k. 33-34v.

${ }^{69}$ Protokoły KPND, Petersburg, 14/25, 15/26 i 18/29 III 1756, SIRIO, t. 136, s. 2, 33 , 35; por. H. Kaplan, op. cit., s. 61.

${ }^{70}$ H. Gross do Elżbiety I, Drezno, 9/21 V 1756 (rel. nr 45), AVPRI, f. 79/1, d. 1756/6a, k. 247-247v.

${ }^{71}$ H. Gross do Elżbiety I, Drezno, 20/31 V 1756 (rel.nr 50), ibidem, k. 263-264v. 
Można zatem odnieść wrażenie, że Gross wywnioskował prawidłowo, iż pierwszy ze wspomnianych reskryptów niósł za sobą konkretne zamierzenia. Natomiast drugi zawierał treści propagandowe, których celem było zasłonięcie rzeczywistych planów.

Wspomniana, pierwsza rozmowa dyplomatów przebiegła w przyjaznej atmosferze. Gross donosił do Petersburga, że Stormont zapewnił go, iż posiada wytyczne swojego dworu, aby żyć z nim w „najściślejszej konfidencji”, rosyjski dyplomata zrewanżował się analogicznym zapewnieniem ${ }^{72}$.

Natomiast Szkot relacjonował szefowi departamentu północnego Robertowi D’Arcy'emu hrabiemu Holdernesse, że Gross odnosił się do niego z „otwartością i przyjaźnią”. Wedle wicehrabiego rosyjski dyplomata był człowiekiem szczerym, o wielkim doświadczeniu i wiedzy, doskonale poinformowanym o sprawach dworu drezdeńskiego. Dowiedział się także o planach zastąpienia Grossa M. Biestużewem-Riuminem, z czym wiązał obawy, przebywanie bowiem nad Łabą dobrze nastawionego wobec dworu londyńskiego rosyjskiego przedstawiciela miało istotny wpływ na interesy Jerzego II w Saksonii ${ }^{73}$.

Gdy się porównuje obie relacje, uderzają różne wnioski, jakie zostały z niej wyciągnięte. Gross uznał raczej wspomnianą wymianę zdań za przejaw kurtuazji i ograniczył się do lakonicznego zrelacjonowania jej przebiegu, tymczasem Stormont z deklaracji rosyjskiego dyplomaty wyciągał daleko idące wnioski. Warto przy tym zwrócić uwagę, jak duże znaczenie Szkot przypisywał czynnikowi personalnemu. Należy jeszcze postawić pytanie o wagę informacji na temat planowanej zmiany w obsadzie rosyjskiej placówki w Dreźnie. Do relacji J. Funckego z Petersburga (1 III 1756) dołączony był tekst listu wielkiej księżnej Katarzyny Aleksjejewnej do A.P. Biestużewa-Riumina, w którym żona następcy tronu ostrzegała kanclerza m.in. przed planami wysłania na placówkę do Drezna skonfliktowanego $\mathrm{z}$ bratem marszałka dworu ${ }^{74}$. Był to najprawdopodobniej element „przecieku kontrolowanego" zastosowany przez kanclerza ${ }^{75}$, zatem Stormont nie przekazywał do Londynu szczególnej tajemnicy.

Przybycie Stormonta do Drezna zbiegło się z dotarciem nad Łabę informacji o traktacie wersalskim. Gross donosił swojemu dworowi, że

${ }^{72}$ H. Gross do Elżbiety I, Drezno, 31 V/11 VI 1756 (rel. nr 54), ibidem, k. 293v.

${ }^{73}$ Stormont do Holdernesse'a, Drezno, 16 IV 1756 („separate”, pr. 24 VI), TNA, SP $88 / 78$, k. 45-46v.

${ }^{74}$ W. Konopczyński, Polska $w$ dobie, s. 145-146, 375-378; o tym, że M.P. Biestużew-Riumin planował zastąpić Grossa w Dreźnie, donosił Williams już 2 grudnia 1752 r., (ibidem, s. 371), on sam usilnie upraszał Woroncowa o tę nominację, M.P. Biestużew-Riumin do M.I. Woroncowa, Drezno, 12/23 III 1754, AKV, t. 2, s. 282-283; por. М. Ю. Анисимов, op. cit., s. 68-69.

${ }^{75}$ T. Szwaciński, op. cit., s. 207-208, 244-245. 
Drezno nie zostało do tej pory zaproszone do traktatu, jednak informacja o zbliżeniu francusko-austriackim wywołała nad Łabą ogromną radość; liczono na akces Rosji i zmniejszenie zagrożenia ze strony Fryderyka II ${ }^{76}$. Stormont natomiast, wedle Grossa, podkreślał niewdzięczność Wiednia wobec Jerzego $\mathrm{II}^{77}$, co było oficjalnym stanowiskiem dyplomacji króla Anglii. Suchy, faktograficzny ton tego doniesienia tworzy wyraźny kontrast z ogromnymi nadziejami, jakie brytyjski dyplomata wiązał z rzekomym anglofilstwem Grossa.

14 czerwca wicehrabia odbył rozmowę z Brühlem. Wedle własnej relacji Stormont wyraził nadzieję, że Saksonia nie przystąpi do traktatu wersalskiego. Pierwszy minister odpowiedział, że postępowanie Sasów będzie uzależnione od polityki Petersburga, a także wyrażał swoje przywiązanie do starego systemu i Wielkiej Brytanii ${ }^{78}$.

W najbliższych dniach Brühl przedstawił treść wspomnianej rozmowy Grossowi, Franzowi Sternbergowi i Broglie'owi. Zgodnie z przekazem Grossa pierwszy minister w ten sposób zrelacjonował mu swoją odpowiedź Szkotowi: Sasi nie mieli powodów do zadowolenia z postępowania Londynu podczas ostatnich negocjacji subsydialnych, a Williams oświadczył jakoby w Petersburgu, że nie widział powodu, aby Wielka Brytania miała dawać Sasom jałmużnę. Elektorat dzięki polityce oszczędnościowej obędzie się bez subsydiów, nie wchodząc w ten sposób w żadne zobowiązania. Drezno, pozostając w sojuszu z dworami cesarskimi, będzie słuchało ich rad (szczególnie rosyjskich), nie wykluczając akcesu do traktatu wersalskiego ${ }^{79}$.

Abstrahując od wyraźnej sprzeczności między doniesieniem Stormonta do Londynu a relacją uczynioną przez Brühla Grossowi, dodajmy, że ani w relacjach Stormonta, ani Grossa nie ma wzmianki świadczącej, iż rosyjski dyplomata weryfikował z brytyjskim kolegą wynurzenia czynione mu przez pierwszego ministra.

${ }^{76}$ H. Gross do Elżbiety I, Drezno, 3/14 VI 1756 (rel. nr 57, pr. 25 VI/6 VII), AVPRI, f. 79/1, d. 1756/6a, k. 310v.

77 „В лорде Стормонте я не менше недовольство против сего нового трактата примечаю, не могучи он обойтиться от времени до времени называть неблагодарным венский двор", ibidem.

${ }^{78}$ Stormont do Holdernesse'a, Drezno, 16 VI 1756 (pr. 24 VI), TNA, SP 88/78, k. 42-44v; por. P. Hanczewski, op. cit., s. 191.

79 „Следственно де естли их императорские величества (особливо ВИВ-о) заблагоразсудят королю присоветовать помянутое приступление, или иные совокупно с ними приемлемые и к теперашней конюнктуре относительные меры, то он предсказать может лорду Стормонту, что Его Польское Величество в том готовым себя окажет", H. Gross do Elżbiety I, Drezno, 7/18 VI 1756 (rel. nr 58, pr. 25 VI/6 VII), AVPRI, f. 79/1, d. 1756/6a, k. 313-314. 
A okazji do wymiany informacji nie brakowało. W związku z niedawnym incydentem obrabowania kuriera brytyjskiego w Berlinie Stormont okazał Grossowi list od posła brytyjskiego w Prusach, A. Mitchella, zgodnie z którym przedstawiciel Jerzego II uznawał, że wbrew powszechnym podejrzeniom Fryderyk II nie zlecił tej kradzieży ${ }^{80}$.

Po uzyskaniu informacji o traktacie wersalskim Londyn polecił Robertowi Keithowi, swojemu przedstawicielowi w Wiedniu, pozyskiwanie tamtejszego dyplomaty rosyjskiego, Hermanna Keyserlingka. Zapewniano go o pokojowych zamiarach Fryderyka II i usprawiedliwiano motywy, które skłoniły Jerzego II do zawarcia konwencji westminsterskiej, liczono, że rosyjski dyplomata przedstawi swojemu dworowi korzyści, jakie płynęły z zachowania sojuszu z Wielką Brytanią. Spodziewano się uzyskać od Keyserlingka informacje o stosunku Rosji do traktatu wersalskiego, a także wsparcie wysiłków zawrócenia Wiednia z fatalnej drogi sojuszu z Wersalem. Podobną politykę stosowano także wobec A. M. Golicyna i ambasadora rosyjskiego Hadze, Aleksandra Gawriłowicza Gołowkina (Aleksandr Gavrilovič Golovkin) ${ }^{81}$.

Odpowiadając na pierwsze depesze z Drezna, Holdernesse włączył Stormonta do opisanych powyżej działań. Stwierdził, że nic, co sprzyjałoby zachowaniu dobrych stosunków między Jerzym II i Elżbietą Piotrówną, nie powinno być zaniedbane. Samego Grossa traktowano na dworze londyńskim niemalże jako brytyjskiego agenta wpływu, który oddziaływać miał na własną stolicę po myśli interesów króla Anglii. Dlatego polecono Stormontowi utrzymywanie gorliwej przyjaźni z rosyjskim dyplomatą, aby uzyskać od niego możliwie dużo informacji, dotyczących rzeczywistego nastawienia dworu petersburskiego do przemian na kontynencie. Miało to jednocześnie prowadzić do wykorzystania Grossa jako kanału służącego do oddziaływania na rosyjskiego kanclerza i przekonywania go o fatalnych konsekwencjach, które niosło ze sobą zbliżenie Austrii i Francji. Rosja powinna, zdaniem strony brytyjskiej, temu zapobiec, naciskając na Wiedeń. Jeżeli jednak Austria wytrwałaby na obranej drodze zbliżenia z Francją, strona rosyjska powinna być świadoma, że wzrost potęgi króla arcychrześcijańskiego pozostawał w oczywistej sprzeczności z interesem

${ }^{80}$ H. Gross do Elżbiety I, Drezno, 7/18 VI 1756 (rel. nr 58), AVPRI, f. 79/1, d. 1756/6a, k. 314. O okradzeniu kuriera patrz: P.F. Doran, op. cit., s. 57, 91; P. Hanczewski, op. cit., s. 31 .

${ }^{81} \mathrm{O}$ nadziejach Anglików związanych z osobą Keyserlingka patrz: Williams do Holdernesse'a, Petersburg, 26 VI, 9 VII 1756 (pr. 20 VII, 4 VIII, druga depesza „private and secret"), TNA, SP 91/63, b.p.; F. von Raumer, op. cit., s. 254; Е. Щепкин, op. cit., s. 301-302; P.F. Doran, op. cit., s. 51, 75, 90, 95; P. Hanczewski, op. cit., s. 190-191. 
dworu petersburskiego. Było to wyraźną sugestią dla Rosjan, że w takim wypadku powinni zweryfikować swój sojusz z Marią Teresą ${ }^{82}$.

Stormont zanim otrzymał te wytyczne, donosił do Londynu, że głównym zajęciem dyplomacji francuskiej w Dreźnie i Warszawie było uniemożliwienie swobodnego przemarszu wojsk rosyjskich przez Polskę, w przypadku gdyby Londyn wezwał je na pomoc i prosił o instrukcje, jak temu przeciwdziałać ${ }^{83}$. Wicehrabia donosił ponadto, że Brühl i Gross uważali traktat wersalski za zjawisko przejściowe. Szkot mniemał, że rosyjski dyplomata osobiście nie aprobował zbliżenia austriacko-francuskiego, powstrzymując się jedynie od jednoznacznych deklaracji. Tłumaczył to oczekiwaniem Grossa na instrukcje ${ }^{84}$.

W czerwcu Fryderyk II, uzyskawszy informację o koncentracji wojska rosyjskiego w Inflantach i prawdopodobnej porażce dyplomacji brytyjskiej w Petersburgu, przeprowadził błyskawiczną mobilizację, planując szybkie wyeliminowanie Rosji z ewentualnej wojny. Filozof z Sans-Souci zamierzał wykorzystać starcie i zagarnąć kosztem Rzeczypospolitej Prusy Królewskie lub ewentualnie „tylko” Elbląg, Toruń i Chełmno. Wszelako pod koniec miesiąca (po przejęciu depeszy posła holenderskiego w Petersburgu Marcellisa de Swarta o cofaniu się wojsk rosyjskich) król pruski zrezygnował z tych planów. Wykorzystał także kanał Mitchell-Williams, aby zapewnić dwór

82 „And though the king has no doubt of the steadiness, with which that princess [Elżbieta] will govern herself, nothing should be neglected, that may tend to confirm and augment the most perfect good understanding between His Majesty and the court of Petersburg. M. Gross has been represented to the king as being thoroughly well-inclined to support His Majesty's interest with the empress, his mistress. Your Lordship will therefore cultivate his friendship and acquaintance as much as possible, and endeavour to learn from him the real sentiments of the court of Petersburg upon the present situation of affairs. It might be of service if he would undertake to show count Bestoucheff all the fatal consequences, that may attend an union between the Houses of Austria and Bourbon, supposing it to be permanent, which are best be prevented by the seasonable and strong interposition of the empress of Russia. But should the court of Vienna persist in the erroneous measures, they have lately entered into by the pernicious advice of count Kaunitz, contrary to the opinion of all the empress's [Marii Teresy] old and faithful servants, the interest of Russia should naturally lead that power to oppose the great superiority, which the unnatural alliance will give France over the rest of the world. The complete knowledge M. Gross has of the interests of Europe, and of the Russian Empire in particular, will furnish him (if he is willing to undertake the task) with the proper arguments to be used upon this occasion, and which cannot be safely suggested at large in a letter by the common post", Holdernesse do Stormonta, Londyn-Whitehall, 29 VI 1756, TNA, SP 88/78, k. 50v-53.

${ }^{83}$ Stormont do Holdernesse'a, Drezno, 23 VI 1756 (pr. 8 VII), TNA, SP 88/78, k. $55 \mathrm{v}-55 \mathrm{a}$.

${ }^{84}$ Stormont do Holdernesse'a, Drezno, 26 VI 1756 („private”, pr. 5 VII), ibidem, k. 59v-60. 
rosyjski o wyłącznie obronnym celu swoich działań ${ }^{85}$. Mobilizacja pruskiego wojska nie uszła uwadze rosyjskiego dyplomaty w Dreźnie, który donosił do Petersburga o zagrożeniu ${ }^{86}$.

2 lipca Stormont złożył nową wizytę rosyjskiemu dyplomacie. Wedle relacji Grossa Szkot oświadczył, że ma specjalne polecenie swego dworu, aby żyć z nim w konfidencji, albowiem Jerzy II uważał Elżbietę „za swą najlepszą sojuszniczkę". W związku z ostatnimi wydarzeni zapewnił Grossa, że nadzwyczajne działania mobilizacyjne Fryderyka II spowodowane były jedynie troską o własne bezpieczeństwo. Król pruski podejrzewał bowiem, że traktat wersalski posiadał tajne, wymierzone w niego artykuły. Stormont przekonywał, że było wątpliwe, aby Fryderyk II sam z siebie zamierzał zaatakować Saksonię lub Austrię, ściągnąłby bowiem na siebie jednocześnie oręż Austrii, Francji i Rosji, czyli pierwszych potęg europejskich. Gdyby jednak to nastąpiło, zapewniał Szkot, stałoby się to bez wiedzy i woli Jerzego II $^{87}$.

Natomiast z relacji Stormonta można odnieść wrażenie, że inicjatorem tej rozmowy był Gross, który obszernie omówił przygotowania wojenne Fryderyka II i oświadczył, iż był przekonany o agresywnych zamiarach króla pruskiego. Przedmiot nagłego ataku mogła stanowić Rosja, dowodem czego było założenie pięćdziesięciotysięcznego obozu wojskowego na Pomorzu. Gross poinformował kolegę, że doniósł już swemu dworowi o pruskiej mobilizacji. Zapewnienia Stormonta, iż Fryderyk II nie zaatakuje, nie zrobiły na Grossie wrażenia. Sam Szkot był przekonany, że podejrzenia co do agresywnych planów Fryderyka II były fałszywe. Obawiał się natomiast, że przyczynią one szkód interesom brytyjskim w Dreźnie i Petersburgu, powodując pchnięcie Saksonii i Rosji w objęcia austriackiego odstępcy Albionu $^{88}$.

Wydaje się, że różnice w relacjach wynikają z faktu, że każdy z dyplomatów skupił się przede wszystkim na tym, co powiedziała druga strona; nie zawierają one treści wzajemnie ze sobą sprzecznych.

Obawy, które żywił Gross w odniesieniu do Fryderyka II, zaniepokoiły Londyn. Ustosunkowując się do nich, Holdernesse nakazał Stormontowi przekonywać rosyjskiego dyplomatę, że w opinii Jerzego II, popartej solen-

${ }^{85}$ Е. Щепкин, op. cit., s. 305-306; W. Konopczyński, Polska w dobie, s. 99-100, 346-347; H. Kaplan, op. cit., s. 82-84; P.F. Doran, op. cit., s. 58-61, 91-92.

${ }^{86}$ H. Gross do Elżbiety I, Drezno, 21 VI/2 VII 1756 (rel.nr 64, pr. 13/24 VII), AVPRI, f. 79/1, d.1756/6a, k. 333v.

${ }^{87}$ H. Gross do Elżbiety I, Drezno, 21 VI/2 VII 1756 (rel. nr 65, pr. 12/23 VII), AVPRI, f. 79/1, d. 1756/6a, k. 345-345v.

${ }^{88}$ Stormont do Holdernesse'a, Drezno, 4 VII 1756 (pr. 12 VII), TNA, SP 88/78, k. 64-66v; por. H. Kaplan, op. cit., s. 88. 
nymi zapewnieniami Fryderyka II, przygotowania wojenne króla pruskiego czynione były wyłącznie w celu własnej obrony. Jednakże doniesienia z Drezna, głosiła dalej instrukcja, skłoniły króla Anglii do wysłania rozkazów Mitchellowi, aby uzyskał od króla pruskiego potwierdzenie jego pokojowych zamiarów, co, w opinii brytyjskiej, stałoby się podstawą do zupełnego uśmierzenia rosyjskich obaw ${ }^{89}$.

Wstrzymanie marszu wojsk rosyjskich w Inflantach wywarło duże wrażenie na królu pruskim. W nowych warunkach gotów był on chwilowo dać wiarę Anglikom, że robota petersburska Williamsa zaczęła wreszcie przynosić pożądane efekty. Zaczęły krążyć pogłoski o zbliżeniu rosyjsko-pruskim ${ }^{90}$.

5 lipca Stormont odbył konferencję z pruskim kolegą akredytowanym przy dworze Augusta III, H.D. Maltzahnem. Na pytanie Szkota dotyczące mobilizacji wojsk Fryderyka II Prusak zasugerował, że związane były z planowaną paradą. Stormont replikował uzyskaną wcześniej od Grossa informacją o obozie wojsk pruskich na Pomorzu, który mógł zaniepokoić stronę rosyjską. Na to Maltzahn odparł, że zgodnie z informacjami dostępnymi w Berlinie, kształtował się już potrójny sojusz Wielkiej Brytanii, Prus i Rosji, i zadał pytanie o bieżące relacje Londynu z Petersburgiem. Stormont nie taił, że zachowanie najściślejszej przyjaźni z Rosją pozostawało priorytetem brytyjskiego systemu, zapewniał także, że Jerzy II nie podejmie żadnego kroku, który stałby w sprzeczności ze zobowiązaniami, jakie łączyły go z Elżbietą. W efekcie rozmowa przeistoczyła się w wymianę zdań na temat istoty konwencji westminsterskiej, która ujawniła daleko posuniętą różnicę stanowisk między oboma dyplomatami ${ }^{91}$.

Wicehrabia niezwłocznie poinformował Grossa o opisanej powyżej rozmowie z Maltzahnem. Wedle Szkota rosyjski dyplomata wyglądał na usatysfakcjonowanego taką otwartością i oświadczył, że posiadał instrukcje, aby zapewnić brytyjskiego kolegę o pragnieniu Elżbiety Piotrówny utrzymania przyjaźni z Jerzym II i gorliwym wypełnieniu wszystkich zobowiązań wobec króla Anglii. Od siebie zaś Gross dał zapewnienie, że zobowiązania, które imperatorowa podjęła wobec innych swoich sojuszników

${ }^{89}$ Holdernesse do Stormonta, Londyn-Whitehall, 13 VII 1756, TNA, SP 88/78, k. 70-70v.

${ }_{90}$ Wedle informacji uzyskanych przez Grossa król pruski miał rozgłosić, jakoby minister rosyjski przybył już do Poczdamu, H. Gross do Elżbiety I, Drezno, 21 VI/2 VII 1756 (relacja nr 65) AVPRI, f. 79/1, d. 1756/6a, k. 345-345v. Е. Щепкин, op. cit., s. 307.

${ }^{91}$ Stormont do Holdernesse'a, Drezno, 7 VII 1756 („private”, pr. 16 VII), TNA, SP 88/78, k. 75-78; por. P. Hanczewski, op. cit., s. 66, 83-84. Wizje szerokiego sojuszu Londynu, Berlina, Petersburga i Hagi snuł Fryderyk II już od lutego 1756 r., P.F. Doran, op. cit., s. 40, 49, 78, 95. 
(sugerując z pewnością Marię Teresę i Augusta III), również zostaną wypełnione ${ }^{92}$.

Zauważmy, że rosyjski dyplomata uchylił się od deklaracji, na której w ówczesnych warunkach musiało najbardziej zależeć politykom nad Tamizą, tzn. któremu sojusznikowi Rosja pozostanie wierna, jeżeli Londyn i Wiedeń znajdą się we wrogich sobie obozach. Heinrich Iwanowicz nie doniósł swojemu dworowi o zapoznaniu go przez Stormonta z treścią rozmowy z Maltzahnem. Możemy przypuszczać, że rosyjski dyplomata potraktował rewelacje wicehrabiego jako drugorzędne, donosił już bowiem o sugestiach Fryderyka II dotyczących rzekomego porozumienia prusko-rosyjskiego.

Rychło po uldze, jaką przyniosło Berlinowi wstrzymanie rosyjskiego marszu w Inflantach, Fryderyk II zaczął obawiać się ataku ze strony Marii Teresy i kontynuował przygotowania wojenne ${ }^{93}$.

W drodze z Karlsbadu do Poczdamu 6 lipca przejeżdżał przez Drezno pruski generał Jacob Keith. Podczas krótkiej wizyty, którą przy tej okazji złożył Stormontowi, oświadczył, że nie znał powodów pruskiej mobilizacji, jednak z dostępnych mu informacji nie wynikało, aby król pruski planował wojnę, gdyż Hohenzollern był usatysfakcjonowany swoimi dotychczasowymi zdobyczami. Wszelako, zapewniał generał, jeżeli Fryderyk II rozpocząłby wojnę, stałoby się to wtedy, gdyby był przekonany, że sam niebawem stanie się przedmiotem ataku ${ }^{94}$.

Podobnie jak w przypadku konferencji z Maltzahnem wicehrabia nie omieszkał bez zwłoki przedstawić treść wspomnianej rozmowy Grossowi. Rosyjski dyplomata tym razem wprawdzie przesłał swojemu dworowi informację o enuncjacjach kolegi, jednak (wbrew oczywistym nadziejom Stormonta) ani słowem nie zasugerował, aby można było dawać wiarę wynurzeniom pruskiego generała ${ }^{95}$.

Mimo to Gross cały czas utrzymywał Szkota w przekonaniu, że może sprzyjać interesowi brytyjskiemu na dworze petersburskim. Gdy Stormont otrzymał 11 lipca instrukcje z Londynu (z 29 czerwca), pospieszył do rosyjskiego dyplomaty z zapewnieniami o życzliwości, jaką żywił doń hrabia Holdernesse. Gross zrewanżował się deklaracją, że będzie wykonywał polecenia płynące z Wielkiej Brytanii, wybierając w tym celu od-

${ }^{2}$ Stormont do Holdernesse'a, Drezno, 7 VII 1756 („private”), TNA, SP 88/78, k. $78-78 \mathrm{v}$.

${ }^{93}$ W. Konopczyński, Polska $w$ dobie, t. 1, s. 100-101, 346-347; Е. Щепкин, op. cit., s. 307-308; H. Kaplan, op. cit., s. 86, 88-90.

${ }^{94}$ Stormont do Holdernesse'a, Drezno, 7 VII 1756 (pr. 16 VII), TNA, SP 88/78, k. 72-73.

${ }^{95}$ H. Gross do Elżbiety I, Drezno, 28 VI/9 VII 1756 (rel. nr 67, pr. 14/25 VII), AVPRI, f. 79/1, d. 1756/6a, k. 353v-354. 
powiednią okazję. Podkreślił przy tym, że z powodów taktycznych musi czekać na ustosunkowanie się do sprawy A.P. Biestużewa-Riumina ${ }^{96}$. Takie postawienie sprawy dawało praktycznie nieograniczone możliwości zwodzenia brytyjskiego kolegi.

Prawdopodobnie otrzymane instrukcje skłoniły Stormonta do przedstawienia hrabiemu Holdernesse swych poglądów na temat stosunków Wielkiej Brytanii i Rosji. Dyplomata stwierdził na wstępie, że zachowanie przyjaźni ze wschodnim imperium miało kluczowe znaczenie w brytyjskim systemie, dlatego od swojego przybycia do Drezna wytrwale podtrzymywał przyjazne stosunki z Grossem. Starał się, w miarę możliwości, dowiedzieć od niego o bieżących poglądach i nastrojach panujących na dworze petersburskim, bez której to wiedzy prawidłowe wykonywanie obowiązków w Dreźnie byłoby niemożliwe. Jednocześnie Stormont nawiązywał do zapewnień Grossa o determinacji Elżbiety Piotrówny w wykonaniu zobowiązań wobec Jerzego II $^{97}$. Wicehrabia informował także swój dwór, że Gross uchylał się od udzielania informacji na temat stosunku Petersburga do traktatu wersalskiego, podkreślając, że z powodu choroby kanclerza nie zostały podjęte istotne decyzje w tej sprawie. Jednakże pozycja A.P. Biestużewa-Riumina w prowadzeniu rosyjskiej polityki zagranicznej była, wedle zapewnień Grossa, tak silna, a jego oddanie Jerzemu II na tyle trwałe, że póki żył pieczętarz i wykonywał swe obowiązki, wypowiedzenie zobowiązań wobec króla Anglii nie mogło rzekomo wchodzić w gre $e^{98}$. W oparciu

${ }^{96}$ „Count Gross is much flattered with the favourable opinion Your Lordship has of him, and will with the greatest pleasure do what you desire, but says he must watch a proper opportunity, and wait till such time as he receives something from the great chancellor upon the subject, for he assured, that if he was to offer to give his opinion before, it was asked (which is a liberty he would by no means chose to take) the great chancellor would immediately conclude, that it was a think concerted with me, and that consequently all he could say would have little or no effect", Stormont do Holdernesse'a, Drezno, 11 VII 1756 (pr. 20 VII), TNA, SP 88/78, k. 80v-81v.

${ }^{97}$ Stormont do Holdernesse'a, Drezno, 11 VII 1756 („,secret”, pr. 20 VII), ibidem, k. 83-84. Informacje na temat stanowiska Rosji były wtedy nad Tamizą szczególnie pożądane. 8 lipca 1756 r. odbyła się „cabinet council”, podczas której uznano za wskazane zawarcie z Fryderykiem II aliansu defensywnego, jednak ,this should be postponed until the sentiments of St. Petersburg are explained", P.F. Doran, op. cit., s. 80-81, 96.

${ }_{98}$,As to the actual sentiments of the court of Petersburg with regard to the late treaty, count Gross constantly answers to me, that he can say nothing upon that point, having not, as yet, received a single line upon the subject from his court, which is owning to count Bestucheff's illness. Count Gross is persuaded, that the empress of Russia will take no step without the advice of count Bestucheff, who even when he is least in favour, has the chief direction of foreign affair. The great chancellor's good intentions towards us, count Gross says, we may depend upon, and may be sure, that whilst he lives and has power, the czarina will never change her system, nor take any steps, contrary to the engagements she has with England", Stormont do Holdernesse'a, Drezno, 11 VII 1756, („secret”), TNA, SP 88/78, k. 84-84v; por. P. Hanczewski, op. cit., s. 83, 191. 
o informacje uzyskane m.in. od rosyjskiego kolegi Stormont stwierdzał, że Rosjanie będą zwlekać z ogłoszeniem swojego stosunku do traktatu wersalskiego. Przyczyna tego leżeć miała, zdaniem Szkota, częściowo w chorobie kanclerza i typowej rosyjskiej opieszałości, a częściowo w przemyślanej strategii zmierzającej do uzyskania maksymalnych korzyści z dokonujących się przemian. Ewentualne trzymanie w niepewności brytyjskiego partnera mogło, zdaniem Stormonta, być związane z chęcią wymuszenia większych subsydiów, nie wykluczał także, że przyczyna rosyjskiej zwłoki leżeć mogła w planie zwiększenia osobistych korzyści A.P. Biestużewa-Riumina ${ }^{99}$. Widząc wyłącznie takie powody opóźnień oficjalnej deklaracji dworu petersburskiego w sprawie traktatu wersalskiego, Stormont szedł dalej, stwierdzając, że w związku z tym nie mogło być miejsca na obawy, że Maria Teresa pociągnie Elżbietę na fatalną drogę zbliżenia z Ludwikiem XV. Nie negował jedynie, że między Petersburgiem a Wersalem zostaną wznowione stosunki dyplomatyczne ${ }^{100}$. Stormont raczej wykluczał możliwość odnowienia przyjaznych relacji miedzy Berlinem a Petersburgiem. Przyczynę wrogości między obydwoma dworami widział jednak wyłącznie w osobistych resentymentach, spowodowanych przede wszystkim obraźliwym tonem, w jakim władca Prus wypowiadał się o Elżbiecie Piotrównie ${ }^{101}$.

Tylko niewielka część przypuszczeń Stormonta okazała się słuszna. Wynikało to z niezrozumienia rosyjskiego systemu i mechanizmów decydujących o polityce wschodniego imperium. Jednym z podstawowych celów polityki zagranicznej Petersburga było złamanie siły Fryderyka II,jako władcy, który zagrażał pozycji Rosji w Polsce i Szwecji. Co do tej zasadniczej

99 Stormont do Holdernesse'a, Drezno, 11 VII 1756 („secret”), TNA, SP 88/78, k. $84 \mathrm{v}-86$.

100 „These reason may occasion a considerable delay, but I hope there is no room to apprehend, that the court of Vienna, even if they should persist in their present erroneous system, will be able to draw Russia over to it, and unite that power with France, though it is not impossible that the czarina may carry her complaisance for the empress queen so far as her desire to receive a minister from France and send one thither", ibidem, k. 86-86v; por. P. Hanczewski, op. cit., s. 191.0 możliwości wznowienia stosunków francusko-rosyjskich wiedziano w Londynie co najmniej od końca таја, С. М. Соловьев, ор. cit., s. 364-366.

101 Stormont do Holdernesse'a, Drezno, 11 VII 1756 („secret”), TNA, SP 88/78, k. $86 \mathrm{v}-87 \mathrm{v}$. Poglądy podobne do reprezentowanych przez Stormonta i Williamsa (o czym niżej) były już nad Tamizą znane. P.F. Doran, opierając się na depeszy Holdernesse'a do Mitchella (9 VII 1756), napisał: „Holdernesse's guiding rule was that it is more from intrigue than from political principle that we have anything to fear from the court of Russia" (op. cit., s. 74, 95). Można to zinterpretować jako próbę zwodzenia Fryderyka II, ale uwzględniając przybyłe później do Londynu relacje obu dyplomatów, możemy suponować, że Brytyjczycy istotnie wierzyli, iż polityka rosyjska była efektem personalnych sentymentów i bieżących intryg. 
sprawy nie mogły istnieć różnice między Woroncowem a Biestużewem-Riuminem. Traktat subsydialny z Wielką Brytanią był także podporządkowany temu celowi, a anglomania A.P. Biestużewa-Riumina nie mogła stać w sprzeczności z jego realizacją. W procesie przemiany systemu europejskiego w $1756 \mathrm{r}$. Rosja musiała pozostać w obozie antypruskim.

Dodajmy jeszcze, że niemal w tym samym czasie sytuacja na dworze petersburskim była przedmiotem wszechstronnej analizy Williamsa, który jako wiarygodne przekazywał zapewnienia A.P. Biestużewa-Riumina, że gdyby (co mało prawdopodobne) doszło do akcesu Rosji do traktatu wersalskiego, byłby to stan nietrwały z uwagi na nieprzezwyciężalne sprzeczności interesów na terenie Polski i Szwecji. Kanclerz prosił o cierpliwość i zapewniał, że w ciągu sześciu miesięcy przywróci swój dwór „into a right way of thinking”. Walijczyk liczył także na młody dwór - Piotra i Katarzynę $e^{102}$.

Mimo dość nieprzyjemnego tonu wspomnianej rozmowy Stormonta z Maltzahnem dalsze dni przyniosły ocieplenie klimatu między obydwoma dyplomatami, zwłaszcza że Prusak zapewniał Szkota, iż posiada instrukcje nakazujące mu żyć z brytyjskim kolegą w konfidencji i przyjaźni. Stormont deklarował hrabiemu Holdernesse, że zamierzał odwzajemnić tę postawę z uwagi na wspólnotę interesów Jerzego II i Fryderyka II.Jednocześnie jednak podkreślał, że musiał to robić w taki sposób, aby nie zaszkodziło to jego relacjom z Grossem, które pozostawały jednym z priorytetów brytyjskiego dyplomaty ${ }^{103}$.

W lipcu Fryderyk II prowadził starania, aby za pośrednictwem brytyjskim zapewnić polityków wschodniego imperium, że pruskie przygotowania wojenne mają wyłącznie obronny charakter, a on sam pragnie pokoju i dobrych relacji z Rosją. Odpowiednie kroki zostały podjęte, mimo że filozof z Sans-Souci w tym samym czasie tracił wiarę w możliwość utrzymania przez Londyn sojuszu z Petersburgiem ${ }^{104}$. Do pracy tej została wciągnięta także brytyjska placówka w Dreźnie ${ }^{105}$.

102 Williams do Holdernesse'a, Petersburg, 6-9 i 9 VII 1756 (pr. 4 VIII, druga depesza „private and secret”), TNA, SP 91/63, b.p.; patrz też odpis tegoż, BC, rkp. 1983, s. 645-648; H. Kaplan, op. cit., s. 78. Poglądy Williamsa zostały przedstawione przez A. Mitchella Fryderykowi II, Е. Щепкин, op. cit., s. 308-309, 318. O prawdopodobieństwie przystąpienia Rosji do traktu wersalskiego informował w tym czasie Brytyjczyków A. G. Gołowkin (ibidem, s. 308).

103 Stormont do Holdernesse'a, Drezno, 14 VII 1756 (pr. 24 VII), TNA, SP 88/78, k. 91-92.

${ }^{104}$ H. Gross do Elżbiety I, Drezno, 8/19 VII 1756 (rel. nr 72, pr. 26 VII/6 VIII), AVPRI, f. 79/1, d. 1756/6a, k.370v-371; Williams do Holdernesse'a, Petersburg, 10 VIII 1756 (pr. 4 IX), TNA, SP 91/63, b.p.; H. Kaplan, op. cit., s. 93; P.F. Doran, op. cit., s. 60-63, 70, 92.

${ }^{105}$ P.F. Doran, op. cit., s. 62, 92 (powołuje się na list Mitchella do Stormonta z 10 VII 1756). 
15 lipca Stormont okazał Grossowi list od Mitchella, z którego wynikało, że Fryderyk II nie zamierzał atakować swych sąsiadów, szczególnym zaś pragnieniem króla Prus było nawiązanie dobrych stosunków z Rosją. Gross, opisując sprawę swojemu dworowi, stwierdził, że nie warto było polegać na tych zapewnieniach, stały one bowiem w jaskrawej sprzeczności z informacjami dochodzącymi z innych źródeł ${ }^{106}$.

Stormont zauważył, że wspomniany list nie wywarł na rosyjskim dyplomacie żadnego wrażenia. Szkot uznał, że przyczyną antypruskiej postawy Grossa była „nałogowa nienawiść” (,inveterate hatred”) dworu petersburskiego do Fryderyka II. Dyplomata uznał, że osobista niechęć Elżbiety Piotrówny do króla pruskiego powodowała przewagę wrogów Wielkiej Brytanii nad Newą, tym bardziej że podobnymi uczuciami wobec Fryderyka II pałał A.P. Biestużew-Riumin ${ }^{107}$.

Informacje przychodzące z Prus do Drezna zaczęły wystawiać na próbę wiarę Stormonta w pokojowe intencje Fryderyka II. Król pruski miał wydać wojskom rozkaz, aby były gotowe do wyruszenia w pole. Dyplomata brytyjski podkreślił, że Sasi byli przekonani, iż Elżbieta Piotrówna dochowa sojuszniczych zobowiązań wobec Marii Teresy. Uważał przy tym, że wszystkie informacje, które przychodziły do Drezna o pruskich przygotowaniach wojennych, docierały do Petersburga wyolbrzymione. Następnie służyły nad Newą wrogom Fryderyka II. W rozmowach z rosyjskim kolegą Szkot ponawiał argumenty, że intencją Fryderyka II nie mogło być rozpoczęcie wojny, gdyż na niesprowokowanym zaatakowaniu Marii Teresy król pruski wyłącznie straciłby, ściągając na siebie wspólny atak wszystkich dworów mających defensywne alianse z Austrią. Ogólną odpowiedzią Grossa na sugestie Stormonta było, że „przypuszczenia i spekulacje” nie mogą mieć większego znaczenia od faktów, a także dodał złośliwie, iż zgadza się ze Szkotem tylko w tym, że jeżeli Fryderyk II rozpocznie wojnę, to będzie tego serdecznie żałował. Na wynurzenia Stormonta, iż król pruski jedynie pragnie zapobiec wymierzonemu weń aliansowi, Gross odpowiedział z irytacją, że jedynym zamiarem Fryderyka II było atakować ${ }^{108}$. Po takiej wymianie zdań Stormont nabrał poważnych obaw, że podejrzenia Grossa co do planów króla pruskiego będą oddziaływały na dwór petersburski i mogą stać się argumentem za akcesem Rosji do traktatu wersalskiego ${ }^{109}$.

${ }^{106}$ H. Gross do Elżbiety I, Drezno, 5/16 VII 1756 (rel. nr 70, pr. 22 VII/2 VIII), AVPRI, f. 79/1, d. 1756/6a, k. 360-361.

107 Stormont do Holdernesse'a, Drezno,18 VII 1756 (pr. 27 VII), TNA, SP 88/78, k. 97-99v.

108 Stormont do Holdernesse'a, Drezno, 21 VII 1756 (pr. 4 VIII), TNA, SP 88/78, k. 100-103; por. H. Kaplan, op. cit., s. 88.

109 „From several things count Gross has dropt, I begin to be afraid that he imag- 
26 lipca Stormont poinformował Grossa, że otrzymał właśnie depeszę od hrabiego Holdernesse (z 13 VII 1756), donoszącą, że do Jerzego II dotarły zapewnienia Fryderyka II, iż nie zamierzał rozpocząć wojny. Jak można wnosić z relacji rosyjskiego dyplomaty, zdeterminowany Szkot twórczo rozwinął treść owej depeszy, zapewniał bowiem Grossa, że król pruski oświadczył, iż był gotowy dać także Elżbiecie Piotrównie zapewnienie $\mathrm{w}$ tej sprawie ${ }^{110}$. Komentując te informacje, rosyjski dyplomata stwierdził, że jeżeli rzeczywiście Fryderyk II uczynił takie oświadczenie, to podyktowane było ono jedynie obawami i służyło wywołaniu kryzysu w stosunkach Petersburga z Wiedniem ${ }^{111}$. Stormont ukrył przed własnym dworem przekroczenie przez siebie instrukcji, zamiast tego bałamutnie zapewniał, że podejrzenia Grossa wobec króla pruskiego malały ${ }^{112}$.

Pod koniec lipca Stormont dokonał analizy sytuacji w Rzeczypospolitej. Konstatował, że wsparcie dla Czartoryskich, jakiego udzielała im Rosja, nie przełoży się na zgodę na konfederację „familii”. Twórcę takiej polityki wschodniego imperium w Polsce Stormont widział w A.P. Biestużewie-Riuminie, który rozumiał, że Rosja nie może zgodzić się na nic, co groziłoby zmianą polskiego ustroju, gwarantującego słabość państwa i jego podporządkowanie wschodniemu sąsiadowi. Zgodnie z własną deklaracją Stormont odbył na te tematy kilka rozmów z Grossem (o żadnej z nich rosyjski dyplomata nie wspominał we własnych relacjach), podkreślając wspólne z nim zapatrywania. Mniemał także Szkot, że jeżeli Gross otrzyma zlecenie swojego dworu do wyjazdu do Polski na sejm, to będzie działał zgodnie ze wspomnianą zasadą poparcia dla Czartoryskich w zamian za pokój wewnętrzny. Prosił także o instrukcje dla siebie, sugerując, że

ines the suspicion of the king of Prussia's designs will operate strongly at his court, and possibly determined them to accede to the late treaty of Versailles, or thinks at least, that if the czarina should take such a step, this, if not the real motive, will be the pretence, and will be made use of as an excuse and justification", Stormont do Holdernesse'a, Drezno, 21 VII 1756, TNA, SP 88/78, k. 103-103v.

${ }^{110}$ H. Gross do Elżbiety I, Drezno, 15/26 VII 1756 (rel. nr 74), AVPRI, f. 79/1, d. $1756 / 6 a$, k. 375 .

111 „Которое, ежели основано, по всенижащему моему мнению, едино должно приписать страху в коем по имеющимся здесь ведомостиям король прусской находится теперь, да склонности его какую либо негоцияцию с ВИВ-ом начать и оную венскому двору омбраж приключить, а естли возможно сего последнего надежду на ВИВ-а вспоможение в случае нужды совсем тщетную учинить", ibidem, k. 375v.

112 „[deszyfra] I am extremely glad to hear that His Majesty has had such strong assurances from the king of Prussia. I have constantly insisted here upon the high improbability of His Prussian Majesty's having any offensive views, and I think that count Gross's suspicions are lessened", Stormont do Holdernesse'a, Drezno, 28 VII 1756 (pr. 8 VIII), TNA, SP 88/78, k. 114. 
powinien pracować wspólnie z dyplomatą rosyjskim na rzecz zachowania w Rzeczypospolitej pokoju wewnętrznego, poprzez niedopuszczenie do otwartej konfrontacji „familii” z dworem Augusta III ${ }^{113}$.

Dodajmy, że Williams (około miesiąca wcześniej) dokonał zupełnie innej analizy. Rozgoryczenie Elżbiety polityką dworu drezdeńskiego w Rzeczypospolitej nie słabło i w związku z tym stracił on szansę na sukcesję tronu polskiego i życzliwość wschodniego imperium. Sukces Jerzego Fleminga na reasumpcji wileńskiej (4 V 1756) sprawił, że Brühl zaczął zabiegać o pojednanie z „familią", mimo to Elżbieta była zdecydowana na poparcie któregoś z Czartoryskich (Augusta bądź Adama Kazimierza) podczas przyszłej elekcji króla polskiego. Spisawszy te informacje, Williams dementował je w post scriptum depeszy, dowiedział się bowiem, iż 8 lipca imperatorowa oświadczyła, że zdecydowana była poprzeć Wettynów w ewentualnych staraniach o tron polski ${ }^{114}$.

Instrukcje, które otrzymał Stormont w sprawie swojego postępowania na zbliżającym się sejmie w Polsce, nakazywały postawę raczej bierną, ograniczającą się do zbierania informacji. Jeżeliby Gross wyraził wobec Stormonta sugestię, że uważa za stosowne, aby Szkot posiadał szczegółowe wytyczne dworu londyńskiego na temat swojego postępowania w Polsce, hrabia Holdernesse obiecywał dyplomacie takowe niezwłocznie wysłać. Równocześnie ponownie nakazywano wicehrabiemu pielęgnowanie przyjaźni z Heinrichem Iwanowiczem ${ }^{115}$.

Można zatem stwierdzić, że podobnie jak w okresie poprzednim sprawy polskie w Londynie rozpatrywano niemal wyłącznie pod kątem stosunków Wielkiej Brytanii z Rosją. Natomiast wschodnie imperium (w przeciwieństwie do okresu wcześniejszego, kiedy to przychylnie patrzyło na współ-

113 Stormont do Holdernesse'a, Drezno, 27 VII 1756, TNA, SP 88/78, k. 107-112v; por. odpis w: BC, rkp. 1983, s. 657-660; W. Konopczyński, Polska $w$ dobie, t. 1, s. 417; P. Hanczewski, op. cit., s. 84.

${ }^{114}$ Williams do Holdernesse'a, Petersburg, 9 VII 1756 (pr. 4 VIII, „Poland”), TNA, SP 91/63, b.p.; por. BC, rkp. 1983, s. 641-644.

115 „I have directed the books of my office to be searched in order to see, how far may be necessary for you to have a credential of the Republic of Poland, but as to instructions for your conduct during the residence of the court in that kingdom, none other can properly be sent you, in the present precarious state of Europe, then to see and observe. You are already well acquainted with the parties existing there, the principles upon which they are founded and the names of the persons who are supposed to beat the head of them. If the Russian minister should at any time suggest the propriety of your receiving particular instructions, you will not fail to apprize me of it. In which case I shall immediately acquaint Your Lordship with His Majesty's resolution", Holdernesse do Stormonta, Londyn-Whitehall, 13 VIII 1756, TNA, SP 88/78, k. 124-125; por. BC, rkp. 1983, s. 663; W. Konopczyński, Polska w dobie, t. 1, s. 416; P. Hanczewski, op. cit., s. 76, 191. 
działanie Albionu na gruncie polskim) w 1756 r. nie wyraziło woli współpracy na terenie Rzeczypospolitej ${ }^{116}$.

Rozmowy, które w początkach sierpnia 1756 r. prowadzili Stormont i Gross, wedle brytyjskiego dyplomaty dawały mu nową okazję do agitowania na rzecz pojednania Petersburga z Berlinem; wskazywał rzekome korzyści, jakie mogło ono przynieść Rosji. Stałą odpowiedzią Grossa było, że całkowicie różnił się od brytyjskiego kolegi i nie sądził, aby w interesie jego dworu leżało zbliżenie z Fryderykiem II. Ponadto otwarcie przedstawił Stormontowi, że wzrost siły Fryderyka II był zbyt wielki, więc w interesie Petersburga nie leżało sprzyjanie temu procesowi. W opinii rosyjskiego dyplomaty na słowie króla pruskiego nie można było polegać, ponieważ sprowadzał on swoich partnerów do roli biernych obserwatorów swych własny ambitnych zamierzeń. Z drugiej strony sojusz z Marią Teresą był dla Rosji pewny i naturalny, gdyż opierał się na wspólnocie interesów obu dworów cesarskich. Stormont na tę deklarację Grossa replikował, że nie miał na myśli żadnego porozumienia rosyjsko-pruskiego, które godziłoby w zobowiązania Petersburga wobec Wiednia ${ }^{117}$. Brytyjski dyplomata przyznawał wobec własnego dworu, że jego wynurzenia nie zrobiły na Grossie wrażenia. Natomiast można odnieść wrażenie, iż rosyjski dyplomata, mimo że wyłożył pryncypia rosyjskiego systemu, mgliście sugerował interlokutorowi, że zmiana antypruskiej polityki Petersburga nie była wykluczona ${ }^{118}$. Komentując rozmowy z rosyjskim dyplomatą, Stormont stwierdził, że w jego mniemaniu praca na rzecz pojednania rosyjsko-pruskiego powinna być ogólnym zadaniem dyplomacji brytyjskiej. Co do samego Grossa nie widział już jednak nadziei na wykorzystanie go w realizacji tego zadania ${ }^{119}$.

W przeciwieństwie do kolegi Gross rozmowy z początków sierpnia opisywał bardzo lapidarnie. Donosił jedynie swojemu dworowi, że Stormont otrzymał od Mitchella list (datowany na 3 VIII 1756), w którym poseł brytyjski w Berlinie zapewniał, że Fryderyk II na tyle zmobilizował już wojsko, iż był gotowy do obrony na każdym kierunku. W związku z tym

116 O polityce Rosji wobec Rzeczypospolitej od stycznia 1756 r. patrz: T. Szwaciński, op. cit., s. 198-316.

117 Stormont do Holdernesse'a, Drezno, 8 VIII 1756 (pr. 16 VIII), TNA, SP 88/78, k. 133-135.

118 ,[deszyfra] I cannot pretend to say that this or anything else that I have said upon this subjects, made any impression upon count Gross. He sometimes tells me that if he should receive orders to talk another language, he knows how to obey, but till then he must persist in his old sentiments, which he thinks agrees both of the interests of his court and of His Majesty", ibidem, k. 135-135v.

${ }^{119}$ Ibidem, k. 135v-136. 
król pruski był jakoby zupełnie niezainteresowany rozpoczynaniem wojny. Wiadomości te były zgodne z deklaracjami Maltzahna, a prawdziwe zamierzenia Fryderyka II pozostawały tajemnicą ${ }^{120}$.

Tymczasem, nabrawszy obaw związanych z austriackimi przygotowaniami wojennymi, Fryderyk II zażądał od Marii Teresy oficjalnej deklaracji, że go nie zaatakuje ${ }^{121}$.

11 sierpnia Gross donosił o informacji uzyskanej od Austriaków, że Fryderyk II, uznawszy wcześniejsze deklaracje dworu wiedeńskiego za niewystarczające, zażądał od Marii Teresy nowego oficjalnego oświadczenia o braku zamiaru zaatakowania Prus. Relacjonując powszechną opinię, Gross donosił, że taki krok króla pruskiego był tylko dowodem na poszukiwanie przez Hohenzollerna pretekstu do rozpoczęcia wojny. Dwa dni później Brühl poinformował Grossa, że również Maltzahn mówił mu o nadzwyczajnych żądaniach pruskich wobec dworu wiedeńskiego. Także Stormont przekazał Grossowi, że uzyskał od Prusaka informację o żądaniach w Wiedniu, dodając, iż Fryderyka II mogła usatysfakcjonować tylko jednoznaczna deklaracja Marii Teresy o braku zamiaru atakowania króla pruskiego. Szkot przekonywał rosyjskiego dyplomatę, że działania Fryderyka II świadczą o szczerych intencjach pokojowych Hohenzollerna. Podobne zapewnienia składał brytyjski dyplomata Grossowi także w następnych dniach ${ }^{122}$.

Stormont, wbrew dotychczasowej praktyce skrupulatnego informowania Londynu o kontaktach z Grossem, tym razem przemilczał fakt rozmowy z rosyjskim kolegą o żądaniach w Wiedniu, donosząc wyłącznie o oświadczeniu przedstawionym mu przez Maltzahna oraz swojej

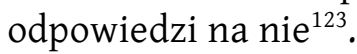

120 „Лорд Стормонт мне сказал, что он письмом господина Митчеля от 3-го сего точно уведомился, что король прусской уже в такое состояние себя привел, что он со всех сторон к обороне готовь, и ни что опасаться не имеет, но что никак не намерен первый тишину нарушать, еже токмо де согласно с изяснением Его Прусского Величества посланника здесь обретающегося, токмо никто поручиться не может о ЕB-а истинном в том намерении", H. Gross do Elżbiety I, Drezno, 29 VII/9 VIII 1756 (rel. nr 80, pr. 17/28 VIII 1756), AVPRI, f. 79/1, d. 1756/6a, k. 391v-392. Echo takich samych treści przekazywanych przez A. Mitchella do Londynu odnajdujemy w instrukcjach dla Williamsa, Holdernesse do Williamsa, Londyn-Whitehall, 20 VIII 1756, TNA, SP 91/63; por. P. Hanczewski, op. cit., s. 197.

${ }^{121}$ W. Konopczyński, Polska w dobie, t. 1, s. 100-101, 346-347; Е. Щепкин, op. cit., s. 308; H. Kaplan, op. cit., s. 87, 92; P. F. Doran, op. cit., s. 63-66, 92-93.

${ }^{122}$ H. Gross do Elżbiety I, Drezno, 31 VII/11 VIII, 2/13 VIII i 5/16 VIII 1756 (rel. nr 81, 82 i 83, pr. 17/28 VIII, 20/31 VIII i 24 VIII/4 IX), AVPRI, f. 79/1, d. 1756/6a, k. $337 \mathrm{v}, 401 \mathrm{v}-403,408$.

${ }^{123}$ Stormont do Holdernesse'a, Drezno, 15 VIII 1756 (pr. 23 VIII), TNA, SP 88/78, k. $142-145 \mathrm{v}$. 
15 sierpnia przybył do Drezna z Petersburga francuski kurier z informacją dla Broglie'a o wznowieniu francusko-rosyjskich stosunków dyplomatycznych. Ambasador króla francuskiego niezwłocznie poinformował o tym fakcie rosyjskiego kolegę. Wedle relacji Grossa nowina ta rychło stała się własnością ogółu ${ }^{124}$. Zgodnie z logiką rosyjskiego systemu nienawiść do Prus okazała się silniejsza niż przyjaźń z Wielką Brytanią.

Rozwój wypadków na arenie europejskiej wywoływał u Stormonta coraz większe obawy. 18 sierpnia donosił, że wprawdzie, wedle jego wiedzy, nie przyszły do Drezna informacje o akcesie Rosji do traktatu wersalskiego, jednakże dwie przesłanki nie skłaniały do optymizmu. Choć nie udało się dyplomacie uzyskać informacji (jak wspomniano wyżej, wedle Grossa, powszechnie dostępnej) o wznowieniu stosunków dyplomatycznych Petersburga z Wersalem, dostrzegł fakt przybycia do Broglie'a wspomnianego kuriera $z$ Petersburga i wnioskował, że wiadomości znad Newy były dla Francji bardzo ważne, gdyż kurier ów już nazajutrz został wysłany w dalszą drogę nad Sekwanę. Ponadto, mimo braku zmiany życzliwego stosunku Grossa do Stormonta, Szkot zauważył, że rosyjski dyplomata jako głównego partnera traktował Sternberga, a jego relacje z Broglie'em były coraz cieplejsze. Stormont nie miał wątpliwości, że wynikało to z wytycznych, które Gross dostał od swojego dworu. Asekurując się, brytyjski dyplomata podkreślał, że w Londynie jego podejrzenia powinny zostać zweryfikowane na podstawie relacji Williamsa ${ }^{125}$.

Choć Stormont nie uzyskał informacji o wznowieniu stosunków rosyjsko-francuskich, nie było to tajemnicą dla polityków w Londynie, ponieważ Williams informował, że Douglas może zostać akredytowany. Dyplomata w Petersburgu umieszczał jednak tę nowinę w kontekście niezwykle jakoby korzystnej sytuacji dla interesów Albionu nad Newą i wręcz sugerował, że przeniesienie kontaktów Wersalu i Petersburga na oficjalną stopę ułatwi mu przeciwdziałanie intrygom dyplomatów króla arcychrześcijańskiego ${ }^{126}$.

Reskrypt cyrkularny z informacją o wznowieniu stosunków dyplomatycznych Petersburga z Wersalem otrzymał Gross 22 sierpnia $1756 \mathrm{r}$. Tekst nawiązywał do reskryptu (z 13/24 kwietnia) o życzliwym odnoszeniu się rosyjskich dyplomatów do francuskich kolegów. Kontynuacją

${ }^{124}$ H. Gross do Elżbiety I, Drezno, 5/16 VIII 1756 (rel. nr 83), AVPRI, f. 79/1, d. 1756/6a, k. 409v. O wznowieniu stosunków dyplomatycznych między Francją a Rosją patrz też: L. Jay Oliva, op. cit., s. 37.

125 Stormont do Holdernesse'a, Drezno, 18 VIII 1756 (pr. 27 VIII), TNA, SP 88/78, k. 149-150.

${ }^{126}$ Williams do Holdernesse'a, Petersburg, 23 VII 1756 (pr. 16 VIII), TNA, SP 91/63, b.p.; por. P. Hanczewski, op. cit., s. 196. 
tamtych decyzji było przyjęcie listów akredytacyjnych A. Mackenziego Douglasa i wysłanie na placówkę do Paryża Fiodora Dmitrijewicza Biechtiejewa (Fëdor Dmitrievič Behteev), z którym polecano Grossowi prowadzić listowną wymianę informacji ${ }^{127}$.

W atmosferze rosnącego napięcia związanego z oczekiwaniem na odpowiedź Marii Teresy na pruskie żądania Stormont stał się biernym obserwatorem postępującego zbliżenia Grossa, Sternberga i Broglie’a, które było efektem kształtującego się nowego potężnego sojuszu. Szkot zauważył, że 23 sierpnia wszyscy trzej wymienieni dyplomaci odbyli u Brühla tajną konferencję, która, wedle przypuszczenia Stormonta, opartego na analizie zachowania Grossa, związana była z deklaracją dworu petersburskiego pospieszenia z pomocą Marii Teresie w przypadku pruskiego ataku. Brytyjski dyplomata deklarował również, że unikał rozmów z Grossem na ten temat, obawiając się ochłodzenia wzajemnych relacji ${ }^{128}$.W dniach następnych niepokój Stormonta wzrastał. Dyplomaci dwóch cesarzowych stale odbywali konferencje z udziałem Broglie'a i Brühla. 26 sierpnia miała się odbyć narada z generałem wojsk saskich Georgem Carlem Dyhernem, co wskazywało, że Rosja, Austria, Francja i Saksonia wspólnie planowały działania. Stormont był przekonany, że dyplomata o takim doświadczeniu jak Gross nie postępowałby w ten sposób, gdyby nie posiadał specjalnych rozkazów. Natomiast zgodnie z informacjami, które uzyskał Stormont z Petersburga, nad Newą podjęto decyzję, że w przypadku ataku Fryderyka II na Marię Teresę Rosja udzieli jej pomocy, czego nie zamierzano jakoby czynić, gdyby to cesarzowa królowa rozpoczęła działania zbrojne ${ }^{129}$.

Przypuszczenia wicehrabiego, że rosyjski dyplomata ogłaszał wolę swojego dworu pospieszenia z pomocą Marii Teresie, były trochę na wyrost, Gross bowiem nie otrzymał jeszcze odpowiednich reskryptów. O wspomnianej konferencji (23 sierpnia) i naradzie (26 sierpnia), Gross w relacjach milczał, zapewne nie uważając tych wydarzeń za szczególnie istotne.

Już po pierwszym żądaniu wobec Austriaków Fryderyk II zdecydował się na uderzenie wyprzedzające wymierzone w Marię Teresę. Nakazał jednak uprzednio swojemu posłowi w Wiedniu Johanowi Klingräffenowi

127 Elżbieta I do H. Grossa, Petersburg, 23 VII/3 VIII 1756 (reskrypt cyrkularny nr 40), AVPRI, f. 79/1, d. 1756/5, k. 166-166v. H. Gross do Elżbiety I, Drezno, 12/23 VIII 1756 (rel. nr 86, pr. 29 VIII/9 IX), AVPRI, f. 79/1, d. 1756/6a, k. 418v-419.

128 Stormont do Holdernesse'a, Drezno, 25 VIII 1756 (pr. 4 IX), TNA, SP 88/78, k. $156-158 \mathrm{v}$.

${ }^{129}$ Stormont do Holdernesse'a, Drezno, 28 VIII 1756 (pr. 7 IX), ibidem, k. 159-160v. Już 6 sierpnia Holdernesse pisał do Mitchella, że stawiając się w roli agresora, Fryderyk II popchnie Rosję do obrony Austrii (P.F. Doran, op. cit., s. 86, 97), podobnie przekonywał Williams (depesza do Londynu, 4 IX 1756, TNA, SP 91/64 b.p.). 
zarzucić dworom cesarskim, że zawarły traktat zaczepny przeciwko Prusom, a zwlekały wyłącznie z powodu nieprzygotowania Rosjan. Maria Teresa odpowiedziała, dementując wyłącznie fakt zawarcia z Rosją traktatu ofensywnego ${ }^{130}$.

Gdy 28 sierpnia Gross złożył wizytę brytyjskiemu koledze, okazał stanowczą dezaprobatę wobec słów, jakie zostały użyte pod adresem dworu petersburskiego przez Klingräffena. Szczególnie oburzenie wyraził wobec insynuacji, że między dwoma cesarzowymi zawiązany został spisek, prowadzący do zaatakowania Prus, który został rzekomo odłożony wyłącznie z powodu braków kadrowych i w zaopatrzeniu w armii rosyjskiej. Nawiązując do wcześniejszych zapewnień Stormonta o woli Fryderyka II pojednania z Rosją, Gross ironicznie oświadczył, że było niespotykane, aby władca żywiący wspomniane pragnienia jednocześnie obrażał Rosję takimi insynuacjami. Bezradny Stormont próbował tylko uspokajać rozsierdzonego Grossa. Szkot przy tym ostrzegł swój dwór, że należało się spodziewać złego odbioru wspomnianego manifestu nad Newą ${ }^{131}$.

O rozmowie 28 sierpnia $1756 \mathrm{r}$. w swych relacjach Gross milczał.

Kilka godzin po spotkaniu z Grossem Stormont widział się z Maltzahnem, który poinformował, że właśnie przybył z Berlina kurier z informacją, iż Fryderyk II nie był usatysfakcjonowany odpowiedzią Marii Teresy i postanowił natychmiast rozpocząć wojnę z Austrią. Nazajutrz

${ }^{130}$ Е. Щепкин, op. cit., s. 308-312, 547-548; H. Kaplan, op. cit., s. 92-93; P.F. Doran, op. cit., s. 66,93 .

131, ,[deszyfra] In a visit count Gross made me this afternoon, he complained to me extremely of the extraordinary and indecent manner, with which the king of Prussia had spoken of his court in the memorial M. Klingraffen presented before his last audience, particularly of that part of it, where His Prussian Majesty says, that the two Empress had formed a design of attacking him last spring, but that they had been obliged to defer the execution of their project, because the court of Russia wanted men to recruit their army, sailors to man their galleys, and even bread to support their troops. Count Gross said, that it was very extraordinary that, at the time the king of Prussia declared, he wished to be upon good terms with the court of Russia, he should treat them so disrespectfully, and by calling their power in question, and insinuating that they had the inclination, but wanted the ability to attack him, should force them, in a manner to convince him and the world of the contrary, by exerting their whole strength against him. I had but little to say to this, and as I thought it a delicate subject for me to meddle with, I contented myself with endeavouring to explain away, and soften the express words, that had given offence, but made no kind of impression upon count Gross, who showed more warmth and passion, than I ever knew him do upon any occasion. I own, My Lord, I dread the effect this will have at Petersburg, and the use, that will be made of it to inflame the passion of a princess, conscious of her own power and greatness, and of a temper to resent, in the strongest manner, everything that carries the least appearance of contempt", Stormont do Holdernesse'a, Drezno, 28 VIII 1756 („separate”, pr. 7 IX), TNA, SP 88/78, k. 165-167v. 
Prusak zażądał swobodnego przemarszu przez Saksonię dla wojsk swego króla ${ }^{132}$.

29 sierpnia Brühl oświadczył Grossowi, Sternbergowi i Broglie’owi, że August III, próbując grać na zwłokę, odpowiedział Prusakowi, iż musi się naradzić ze swoimi ministrami. Pierwszy minister obiecał dyplomatom trzech mocarstw uprzednio zakomunikować saską odpowiedź, uprzedzając, że elektorat nie był w stanie stawiać zbrojnego oporu gwałtowi ${ }^{133}$.

Zanim jednak dwór drezdeński ustosunkował się do pruskich żądań, Fryderyk II ze swą armią rozpoczął przemarsz przez Saksonię oraz eksploatację nadłabskiego elektoratu.

Niebawem (4 września) Gross otrzymał reskrypt, w którym zapowiadano obronę Saksonii na wypadek pruskiej agresji, a nieco później cyrkularzem nakazywano mu zadeklarować, że Rosja wypełni wszystkie swoje zobowiązania wobec Marii Teresy. Wprawdzie Ludwik XV nie został jeszcze wymieniony jako sojusznik Rosji, lecz nie wspomniano także o zobowiązaniach Petersburga wobec Jerzego II. Nie mogło budzić wątpliwości, że jeżeli imperatorowa Elżbieta przezwycięży kłopoty zdrowotne, w rozpoczynającej się wojnie Rosja stanie we wrogim wobec Prus obozie. Akces wschodniego imperium do traktatu wersalskiego dokonał się 31 XII 1756/ 11 I $1757^{134}$.

Podsumowując, należy stwierdzić, że przez cały opisywany okres Gross trzymał Stormonta niejako w rezerwie, tzn. utrzymywał z nim poprawne stosunki, rozumiejąc, że dla Rosjan partner brytyjski po traktacie westminsterskim stracił wiarygodność. Przy porównaniu relacji obu dyplomatów uderza podstawowa konstatacja. Dla Stormonta relacje z Grossem były sprawą o znaczeniu podstawowym. Przyczyną tego było przekonanie dworu londyńskiego, że może on wpływać na politykę Petersburga w korzystny dla siebie sposób, przeciągając na swoją stronę rosyjskich polityków. Z drugiej strony w relacjach Grossa Stormont był ledwie zauważany, a dyplomata nie przywiązywał do kontaktów z nim większej wagi, poddając surowej krytyce przekazywane mu przez Szkota informacje. Choć w żadnym z reskryptów nie napisano mu tego

132 Stormont do Holdernesse'a, Drezno, 28, 29 VIII 1756 (pierwsza relacja „private", obie pr. 7 IX), TNA, SP 88/78, k. 168-169v, 170-173v.

${ }^{133}$ H. Gross do Elżbiety I, Drezno, 18/29 VIII 1756 (rel. nr 91, pr. $3 / 14$ IX 1756), AVPRI, f. 79/1, d. 1756/6a, k. 439-440v.

${ }^{134}$ Elżbieta I do H. Grossa, Petersburg, 29 VII/9 VIII 1756 (reskrypt nr 45, wysłany 3/14 VIII, otrzymany przez Grossa 4 IX), AVPRI, f. 79/1, d. 1756/5, k. 175-176; Elżbieta I do H. Grossa, Petersburg 24 VIII/4 IX 1756 (reskrypt cyrkularny nr 46), ibidem, k. 208-211v. O petersburskich kalkulacjach na wypadek śmierci imperatorowej: C. M. Coловьев, ор. cit., s.339-354; H. Kaplan, op. cit., s.101-113. O akcesie Rosji do traktatu wersalskiego L. Jay Oliva, op. cit., s. 56-57; H. Kaplan, op. cit., s. 117-121. 
wprost, można przyjąć, że Gross rozumiał, iż po konwencji westminsterskiej poprawne stosunki z Londynem miały dla Petersburga znaczenie wyłącznie jako element zasłaniający prawdziwe cele. Błędne diagnozy Szkota miały swoje źródło w ogólnej bezradności, jaką wykazała się brytyjska dyplomacja wobec wyrafinowanej strategii Rosjan.

Wydaje się, że obieg informacji między gabinetami i placówkami dyplomatycznymi oraz opinią publiczną w pełnych gorączkowej krzątaniny miesiącach poprzedzających wybuch wojny siedmioletniej wymaga dalszego systematycznego rozpoznania ${ }^{135}$. Warto także podkreślić, że arkana gry wschodniego imperium w latach 1755-1756 wciąż są zagadnieniem stosunkowo słabo zbadanym przez naukę historyczną, zwłaszcza od strony, podstawowych w tym zakresie, źródeł rosyjskiej proweniencji ${ }^{136}$. Szczególnie cenne, z punktu widzenia opisanych powyżej zjawisk, byłoby przedstawienie stosunków R. Keitha z H. Keyserlingkiem w Wiedniu między rozpoczęciem negocjacji francusko-austriackich a wybuchem wojny siedmioletniej ${ }^{137}$.

Nadzieje, jakie wiązali Anglicy z osobą Grossa, skłaniają jeszcze do przypomnienia uwagi Jerzego Michalskiego. Opisując osiem lat późniejsze starania „familii” o pozyskanie dla swych celów H. Keyserlingka, wybitny historyk stwierdzit: „W XVIII w., gdy na Rosję patrzono jako na świeżej kreacji mocarstwo europejskie podlegające częstym zmianom i przewrotom pałacowym, przeceniano na ogół znaczenie poglądów i sympatii jednostek w aparacie kierowniczym państwa, a co za tym idzie i możliwość wpływu na politykę cesarstwa poprzez kaptowanie sobie tych ludzi. Zapominano o konieczności dostosowania się ich poglądów i sympatii do «najwyższej woli» oraz o wyrobionych i konsekwentnych celach i metodach tej polityki"138.

${ }^{135}$ Doskonały wzór metody badań nad obiegiem informacji w osiemnastowiecznej Europie przyniosła praca: P. Ugniewski, Media i dyplomacja. „Gazette de France” o sejmie rozbiorowym 1773-1775, Warszawa 2006.

${ }^{136}$ Cytowana wielokrotnie w tym tekście praca H. Kaplana przywołuje niektóre ważne fakty, jednak w znacznym stopniu historyk ten pozoruje systematyczną kwerendę rosyjskich archiwaliów. O mankamentach warsztatu tego badacza patrz: D. Dukwicz, Kilka słów na temat historiografii pierwszego rozbioru, w: W. Konopczyński, Pierwszy rozbiór, s. XLVIII-XLIX.

${ }^{137}$ Ostatnio opublikowana praca Maksima Anisimowa fragmentarycznie odsłoniła treść korespondencji H. Keyserlingka z Petersburgiem. Dowiadujemy się m.in., że dyplomacie w Wiedniu wprost nakazano ostrożność w kontaktach z brytyjskim kolegą (op. cit., s. 135-138). Natomiast P. Hanczewski naszkicował zawartość korespondencji Londynu z R. Keithem (op. cit., s. 190-191). Trzeba jednak podkreślić, że przyszły historyk nie będzie mógł się obejść bez samodzielnej kwerendy archiwaliów w Moskwie i Londynie.

${ }^{138}$ J. Michalski, Dyplomacja polska w latach 1764-1795, w: Historia dyplomacji, t. 2, s. 498. 


\section{Russian-British Diplomatic Relations in a Saxon-Polish Context on the Eve of Prussian Aggression. Heinrich Ivanovich Gross and David Murray, Viscount of Stormont (June-August 1756)}

The Russian-British subsidies convention signed on 19/30 September 1755 foresaw that in return for English funds Russia was to keep its army in Livonia. For the Russians it became a measure for breaking the military power of Prussia, while the British wished to isolate France. This difference of views resulted in a convention signed on 16 January 1756 by Great Britain and Prussia, to which St. Petersburg reacted adversely. On the other hand, the Russians welcomed the rapprochement of Austria and France. The diplomacy of the king of England was unable to penetrate the game played by Russia. Relations between David Murray, Viscount Stormont, the British diplomat accredited in Dresden, and his Russian colleague, Heinrich Gross, provide interesting facts associated with British hopes for preserving the alliance with Russia. The representative of George II counted on the Russian diplomat, an attitude also encouraged by instructions received from London ("M. Gross has been represented to the king as being thoroughly well-inclined to support His Majesty's interest with the empress, his mistress"). On the other hand, the reports sent by Gross to St. Petersburg indicate the naiveté of such calculations. The presented facts confirm the statement made by the outstanding Polish historian Jerzy Michalski (1924-2007): "During the eighteenth century, when Russia was perceived as a newly created European power subject to frequent transformations and palace revolutions, the significance of the views and sympathies of individuals in the state apparatus was, as a rule, exaggerated; the same holds true for the possible impact upon the policy of the Empire exerted by attracting such people. The necessity of adapting their views and sympathies to the 'supreme will' was forgotten as were the consistent targets and methods of this policy".

Translated by Aleksandra Rodzińska-Chojnowska 